\title{
ANTICARCINOGENIC FACTORS IN PLANT FOODS : A NEW CLASS OF NUTRIENTS?
}

\section{T. JOHNSON ${ }^{1 *}$, G. WILLIAMSON ${ }^{2}$ AND S. R. R. MUSK ${ }^{1}$}

Departments of ${ }^{1}$ Nutrition, Diet and Health and ${ }^{2}$ Food Molecular Biochemistry, Institute of Food Research, Norwich Laboratory, Norwich Research Park, Colney, Norwich, NR4 7UA

\section{CONTENTS}

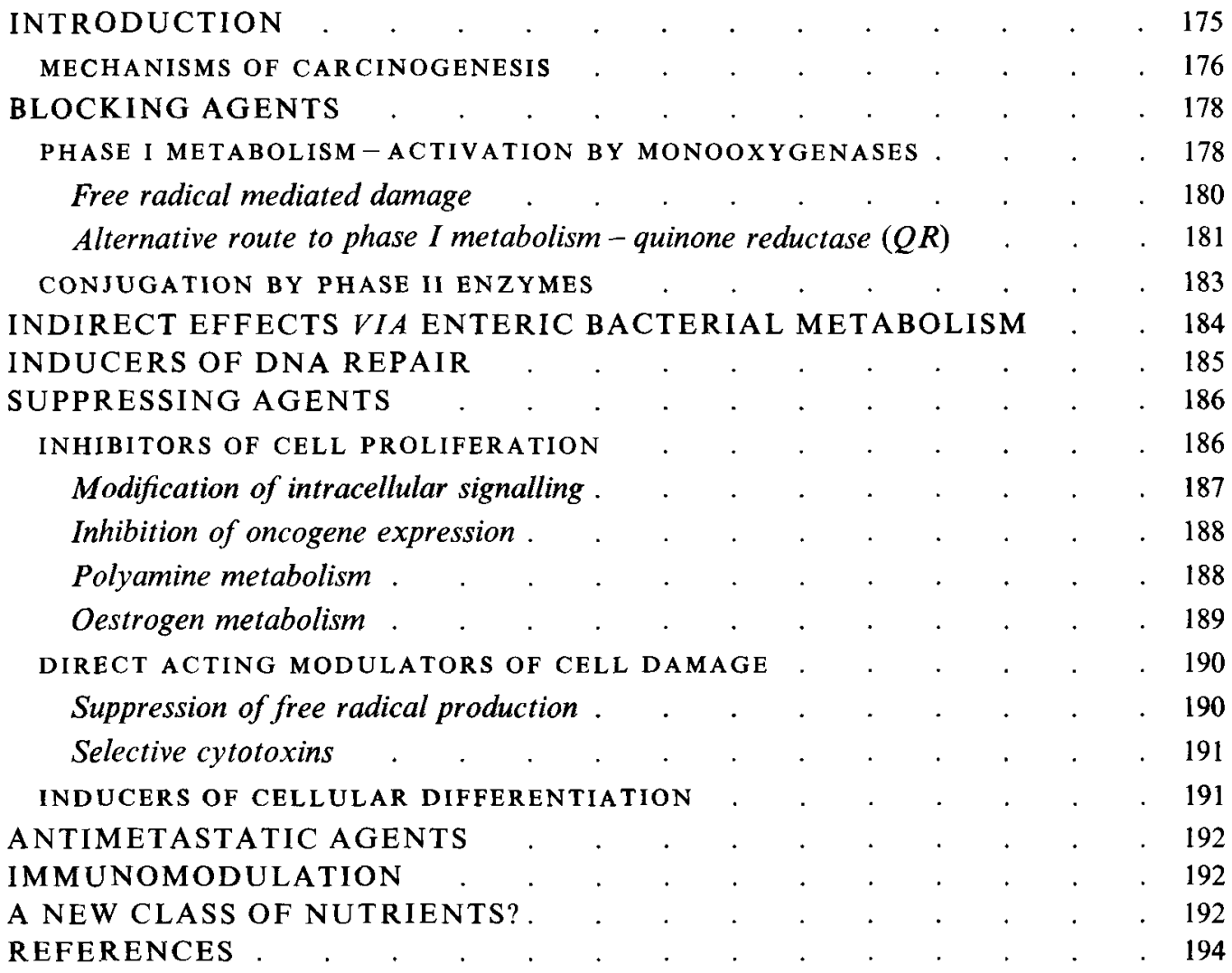

\section{INTRODUCTION}

In their now famous and widely quoted study of the role of environmental factors in the aetiology of cancer, Doll \& Peto (1981) estimated that the proportion of cancer deaths attributable to an adverse effect of diet was approximately $30 \%$ in the USA, the same as that due to tobacco. However, unlike tobacco, for which the risk was well defined and, at

* To whom correspondence should be addressed. 
least in theory, easily avoidable, the effects of diet were considered so complex that their mechanisms of action and their means of manipulation could only be guessed at. One of the strongest signals to emerge from epidemiological studies of diet and cancer incidence over the last decade has been the protective effect of diets rich in vegetables and fruits. Block et al. (1992) reviewed nearly 200 studies of the influence of fruit and vegetable intake on the risk of cancer in man. In 156 of these studies the results were expressed in terms of relative risk, and of these 128 showed a statistically significant protective effect. The results were particularly consistent for cancers of the alimentary tract, lung, breast and female reproductive organs, and were relatively weak only for cancer of the prostate. It is probable therefore that in industrialized societies many of the important effects of diet are protective, and that dietary strategies for the avoidance of cancer require the maximization of these protective effects. Initiatives such as the ' 5 A Day for Better Health' campaign, by which the National Cancer Institute has recently sought to promote the consumption of vegetables and fruit in the USA, are a practical reflection of this principle, but the mechanisms through which the various components of these foods may act remain uncertain.

Interest in the anticarcinogenic effects of foods has a relatively long history. Crabtree (1947) defined an anticarcinogen as any factor "which delays or prevents the emergence of malignant characters in any tissue of any species of organism". Such a broad definition encompasses nutrients as well as other biologically active compounds which fall outside any currently accepted definition of nutrients. Certainly vegetables and fruits are a rich source of micronutrients, including several which are intimately involved in cell proliferation and the maintenance of tissue integrity. These include the folates, and the carotenoids which, together with vitamin $\mathrm{E}$ and ascorbate, are thought also to protect against oxidative damage to DNA and other cellular components (Diplock, 1991). There is good epidemiological evidence to suggest that levels of carotenoids (Stähelin et al. 1991; Ziegler, 1991 ) and vitamin $\mathrm{E}$ in the serum (Murphy et al. 1990; Comstock et al. 1991) are inversely related to risk of cancer. Nevertheless, the protective effects of these nutrients remain to be established, and it may be that high serum levels are merely markers for a high intake of plant foods.

In this paper we are concerned with the very large number of biologically active "nonnutrient' compounds in plant foods for which potentially anticarcinogenic effects have been demonstrated experimentally. The growing realization that such compounds exert biochemical and physiological effects in humans raises important theoretical and practical issues. Many of these substances have previously been regarded as potential toxicants. If their biological activity contributes to the protective effects of fruit and vegetables against cancer, what is the balance of risk and benefit? Furthermore, if their protective value is proven, should they be considered for classification as micronutrients in their own right? In this review we will consider these questions in the light of the known mechanisms of action of the biologically active non-nutrients.

\section{MECHANISMS OF CARCINOGENESIS}

One difficulty in any discussion of anticarcinogenic components of plant foods is the development of a satisfactory classification scheme. The number of secondary metabolites present in fruits and vegetables is very large and many of them appear to inhibit carcinogenesis by more than one mechanism. They are therefore best classified in terms of their biological effects rather than their chemistry, but such a scheme requires a knowledge of their mechanisms of action which in many cases does not yet exist. Much insight has been gained from studies in which vegetables, fruits, or compounds isolated from them 


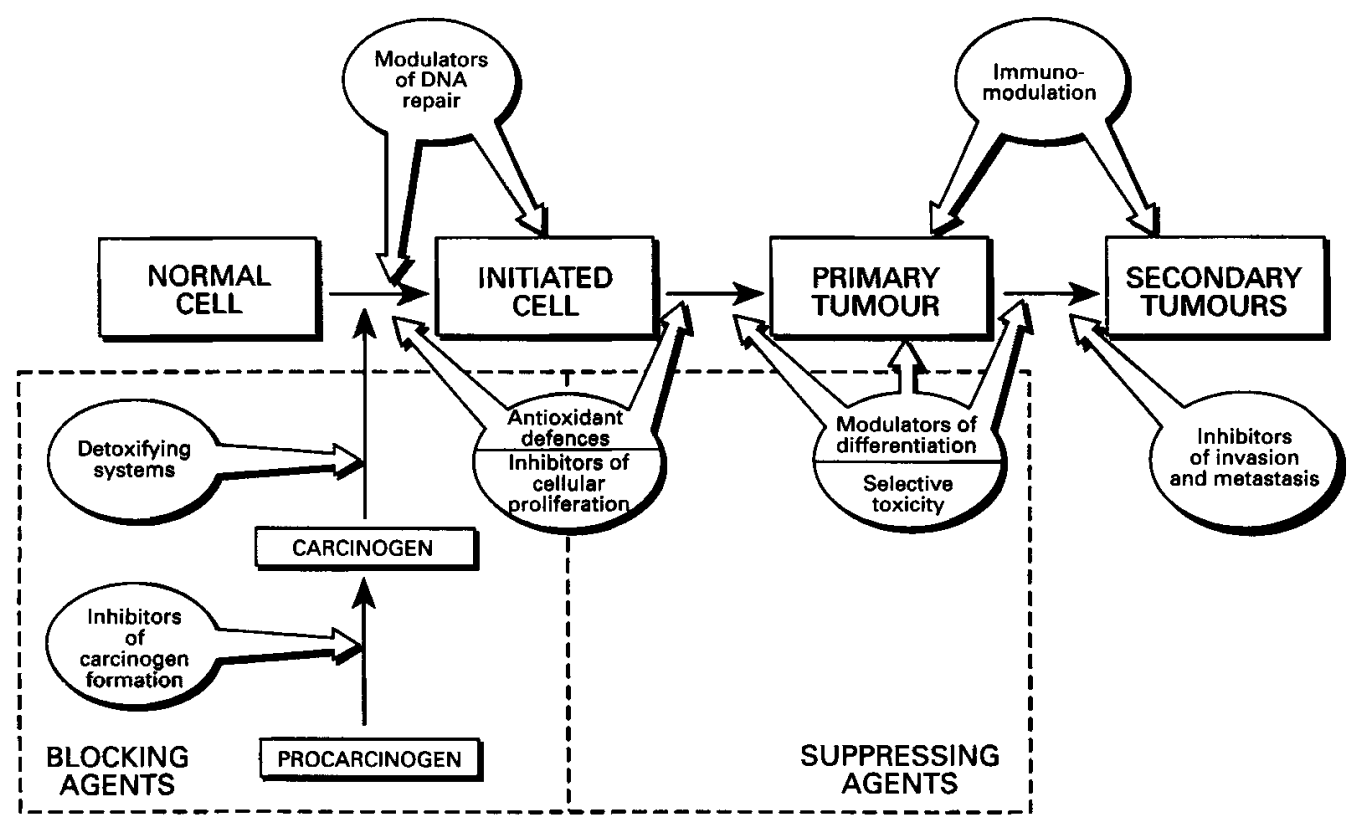

Fig. 1. Mechanisms and sites of interaction whereby protective factors may inhibit the carcinogenic process.

have been administered to experimental animals treated with chemical carcinogens. Before discussing this and other approaches to classification, however, the nature of tumours and the process of carcinogenesis will be briefly reviewed.

Tumour cells are typified by a loss of responsiveness to some or all of the factors regulating cell growth, differentiation and programmed death (apoptosis) in the tissue from which they have arisen. There is usually reduced structural and functional specialization, and malignant tumour cells have the capacity to invade adjacent mesenchyme, and ultimately to migrate to distant sites, giving rise to secondary tumours (metastases). In the simplest model of carcinogenesis the process is assumed to occur in two stages - initiation and promotion. Initiation is the primary event in which cellular DNA undergoes damage which remains unrepaired or becomes misrepaired. The resulting acquired somatic mutation is reproduced at mitosis, giving rise to a clonal population of initiated cells. The initiating event in carcinogenesis is often the result of DNA adduct formation with a genotoxic chemical, but endogenous production of free radicals may be equally important.

Initiated cells do not necessarily give rise to a malignant tumour until they have undergone 'promotion', a process which facilitates their full transformation to an invasive state. Chemical substances which function as promoters are not always genotoxic, but they are often mitogenic, and they may interfere with the expression of genes controlling differentiation and growth. However, some compounds, including polycyclic aromatic hydrocarbons and nitrosamines, are classified as 'complete carcinogens' because they are capable of inducing tumours in experimental animals without the need for exposure to chemical promoters.

Much of the pioneering work on the anticarcinogenic properties of naturally occurring compounds has been carried out by Wattenberg and his coworkers, who proposed a system of classification based on the stage of carcinogenesis at which they act (Wattenberg, 1985). According to this scheme, anticarcinogens are subdivided into two major classes defined 
operationally as 'blocking agents' and 'suppressing agents'. Blocking agents are typically compounds which have been found to be effective when given immediately before or during treatment with chemical carcinogens. They are thought to prevent initiation, either by inhibiting the formation of carcinogens from precursor compounds, or by preventing the active carcinogenic species from acting upon its cellular target. In contrast, suppressing agents are thought to act by preventing the progression of initiated cells to fully transformed tumour cells. Such compounds inhibit the emergence of tumours even when given after treatment with a complete carcinogen or a combination of incomplete carcinogen and promoting agent. We will retain here the general concepts of blocking and suppressing agents, while exploring the extent to which the mechanisms of blocking and suppression have been defined. Fig. 1 summarizes the various possible mechanisms for the inhibition of initiation, promotion and metastasis.

\section{BLOCKING AGENTS}

The first line of defence against chemical carcinogenesis is the ability of tissues such as those of the liver and intestinal mucosa to intercept and detoxify potentially damaging environmental substances. Many carcinogenic compounds enter cells by passive diffusion (Landers \& Bunce, 1991), and are detoxified by several mechanisms. Fig. 2 charts the detoxification pathways which lead to an excretable metabolite of a carcinogen which is represented in this example by a quinone. This figure will form the basis for much of the subsequent discussion. For convenience the metabolic pathway is usually divided into Phase I (which often involves carcinogen activation), Phase II (conjugation) and Phase III (transport out of the cell: Prochaska et al. 1985; Ishikawa, 1992). Paradoxically, the metabolic pathways involved in detoxification may also serve to generate potentially damaging chemical species. Products of phase I reactions in particular may lead to free radical mediated damage of lipids, protein, carbohydrate and DNA, and many of the activated compounds can form DNA adducts. One of the earliest blocking agents to be identified was disulfiram, which inhibits induction of large bowel tumours by 1,2dimethylhydrazine in rodents by preventing its metabolic conversion to an active form (Fiala et al. 1977). Subsequently, a variety of naturally occurring non-nutrient compounds, including aromatic isothiocyanates and indoles from cruciferous vegetables and organosulphur compounds found particularly in allium species, have been found to block chemical carcinogenesis in animals (Wattenberg, 1993). In this section we will review both nonnutrient and some nutrient blocking agents, and show how they play a vital role in regulating the efficiency of carcinogen metabolism. We will also review mechanisms whereby the adverse effects of endogenous free radicals may be blocked by naturally occurring plant constituents.

\section{PHASE I METABOLISM - ACTIVATION BY MONOOXYGENASES}

Hydrophobic carcinogens partition into the cell membrane, where they are activated by membrane bound monooxygenase enzymes, primarily cytochrome P450 (Black \& Coon, 1987; Guengerich, 1992a), and flavin dependent enzymes (Ziegler, 1991). The product of this reaction is an oxygenated compound such as an epoxide which forms a substrate for further metabolism by phase II enzymes (Guengerich, 1992a). The final product of the P450 catalysed reaction may itself be highly carcinogenic (McManus \& McKinnon, 1991). For example, aflatoxin $B_{1}$ is metabolized to aflatoxin- $B_{1}-8,9$-epoxide, which is capable of forming an adduct with the N-7 atom of guanine in DNA (Ishikawa, 1992). Benzo(a)pyrene, 


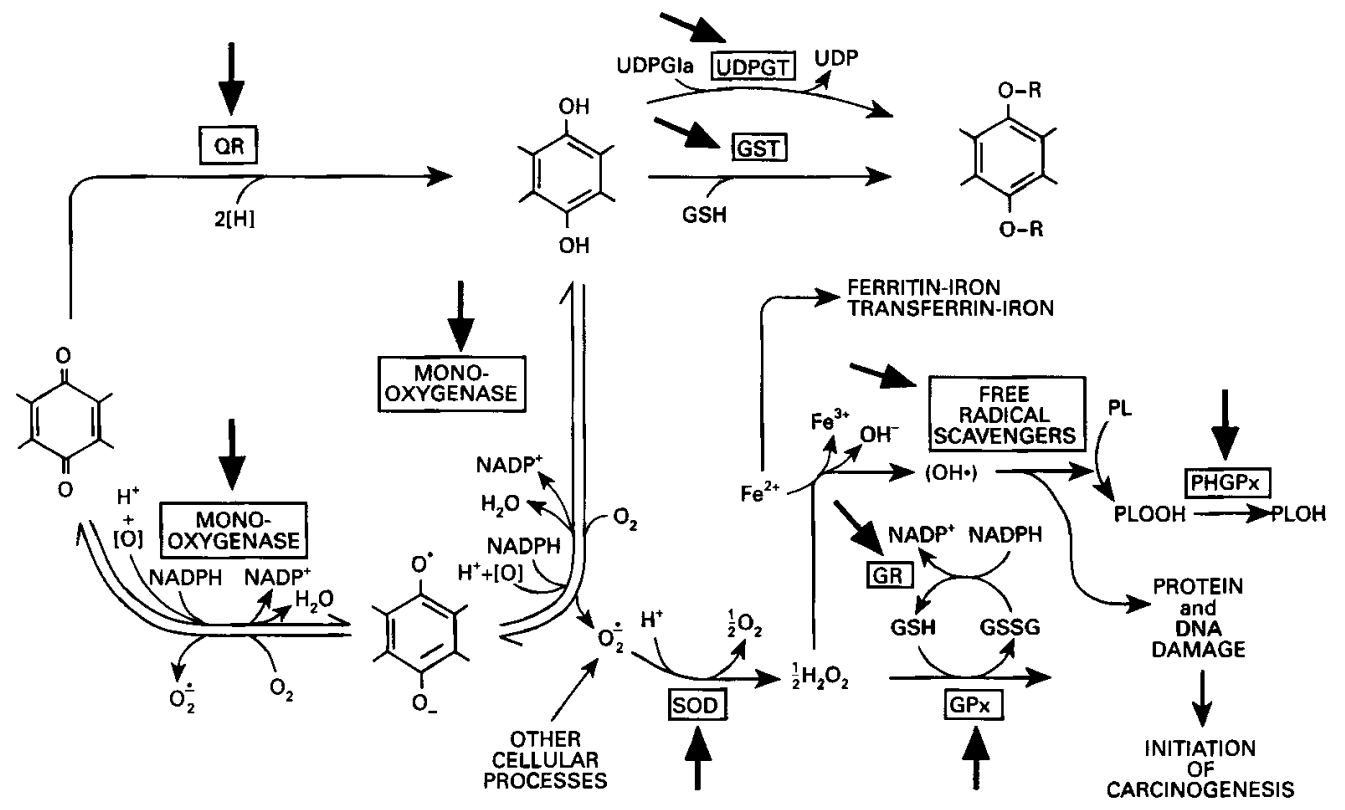

Fig. 2. The inter-relationship between detoxification pathways and free radical mediated oxidative damage, using a quinone xenobiotic as an example. Possible sites for dietary intervention in the detoxification of $2,3,5,6$-tetramethyl-p-benzoquinone are shown by filled arrows. UDPGla, UDPglucuronic acid; PL, phospholipid, its hydroperoxide (PLOOH) and alcohol (PLOH).

a polycyclic aromatic hydrocarbon, is converted to many genotoxic products including phenols and epoxides (Guengerich, 1992a).

Phase I reactions may also give rise to problems for the cell by the production of free radicals. The role of cytochrome $\mathrm{P} 450$ in free radical damage has been investigated by several groups (Castillo et al. 1992; Dai et al. 1993; Ohmori et al. 1993). With reconstituted enzyme systems, in the absence of substrate, reduction of P450 by NADPH or NADH causes the production of reactive oxygen species (Aust et al. 1985). Even in the presence of substrate, coupling is so loose that $50 \%$ of the reducing equivalents appear as superoxide and peroxide, rather than causing oxidation of substrate (Hochstein et al. 1988). These results indicate that the $\mathbf{P} 450$ monooxygenase system may be responsible for the production of reactive oxygen species as a consequence of normal cellular metabolism, although such extreme conditions may not occur in vivo. Certain cytochrome P450 isoenzymes are more prone to the production of reactive oxygen species than others. Thus in animal studies, P450 2E1, an enzyme involved in glycerol oxidation, is poorly coupled, and liver microsomes prepared from animals treated with P450 2E1 inducers exhibit higher rates of $\mathrm{H}_{2} \mathrm{O}_{2}$ production (Clejan \& Coderbaum, 1991). P450 are therefore often considered as pro-oxidants (Dai et al. 1993).

The number of P450 isoenzymes so far found in human tissues exceeds 30 (Guengerich, $1992 a$ ) and a full discussion is beyond the scope of this review. The nomenclature of the P450 isoenzymes is updated in Nelson et al. (1993). The P450 which metabolize xenobiotics belong to classes I, II and III (Guengerich, 1992b). Nutrient status influences phase I metabolism by affecting the transcription, translation or protein stability of cytochrome P450 (Yang et al. 1992). In rats, vitamin E deficiency gives a slight decrease in total P450 (Williams et al. 1992), whereas in the case of vitamin C, both high doses and a deficiency lead to lowered monooxygenase activities (Yang et al. 1992). 
Many dietary non-nutrients bring about much greater changes in P450 levels. Indole-3carbinol, a compound found in cruciferous vegetables, gives rise to a 7.5-fold increase in P450 1A1 in the liver, and a 14-fold increase in the small intestine, when fed to rats at a very high level $(500 \mathrm{mg} / \mathrm{kg}$ body weight) for $14 \mathrm{~d}$ (Wortelboer et al. 1992). Quercetin, a flavonoid which occurs widely in the diet, has been shown to induce P450 levels in vitro. For example it can give rise to increases in P450 1A1 as high as 12-fold in mouse hepatoma cells in culture (De Long et al. 1986). The relevance of such effects in the context of real human diets remains to be established.

There are many examples of drugs and xenobiotics (Forrester et al. 1992), including caffeine (Gandhi \& Khanduja, 1992) and ethanol (Lucas et al. 1992), which increase some P450 involved in phase I metabolism. Other non-nutrient components of human foods which have been shown to have this effect include the flavonoids tangeretin, flavone and nobiletin (Yang et al. 1992). Induction of P450 may, in theory, increase the risk of carcinogenesis. On the other hand diallyl sulphone, a metabolite of diallyl sulphide which is a major flavour component of garlic oil, irreversibly inhibits P450 2E1 (Brady et al. 1991), and this has been proposed as a mechanism for the blocking activity of diallyl sulphone (Brady et al. 1991; Horie et al. 1992). Phenethyl isothiocyanate, a breakdown product from many cruciferous vegetables (Yang et al. 1992), with demonstrated blocking activity (Morse et al. 1989), and naringenin, from grapefruit juice (Fuhr et al. 1993), also inhibit P450 2E1 and 1A2 respectively, and thus both have the potential to decrease phase I metabolism. It has been suggested that inhibition of P450 activity by phenethyl isothiocyanate occurs both through chemical inactivation and by a competitive mechanism (Smith et al. 1993). Again, it must be emphasized that the significance of results obtained in vitro or at very high doses in vivo remains to be properly assessed.

The mechanism of control of P450 1A1 transcription has been extensively studied (Saatcioglu et al. 1990; Fujii-Kuriyama et al. 1992; Gonzalez et al. 1993; Wu \& Whitlock, 1993). The key protein is the Ah receptor, which binds to xenobiotics including dietary compounds, translocates into the nucleus, and then binds to a specific sequence of DNA (the xenobiotic responsive element) upstream of the P450 1A1 gene, which enhances transcription (Gonzalez et al. 1993). The increase in transcription is directly related to the specificity of the $\mathrm{Ah}$ receptor protein as shown for indole-3-carbinol, 3,3'-diindolylmethane (the main gastric conversion product of indole-3-carbinol) and dioxin (Jellinck et al. 1993).

\section{Free radical mediated damage}

Free radical mediated damage occurs as a consequence of normal cellular metabolism, and is exacerbated by poorly coupled redox reactions, including those mediated by cytochrome P450, by free iron released from storage proteins (Minotti et al. 1991; Winterbourn et al. 1991; Reif, 1992), by tissue injury (Powell \& Tortollani, 1992), by reperfusion (Kilgore \& Lucchesi, 1993), and by u.v. light (Godar et al. 1993). Free radical mediated damage is one of the mechanisms involved in initiation of carcinogenesis and such damage is reduced by antioxidants. Nutrient antioxidants such as vitamin $E$ and carotenes play an important role in protecting the membrane and LDL (Bowry et al. 1992; Packer, 1991, 1992; Rousseau et al. 1992; Krinsky, 1993). The amount of vitamin $E$ in membranes is apparently low: about 1 molecule per 1000-2000 phospholipids (Packer, 1992). Vitamin $\mathrm{C}$ is also usually considered to be an antioxidant, and may be involved in regeneration of vitamin $\mathrm{E}$ from tocopheryl radicals (Buettner, 1993). Vitamin $\mathrm{E}$ and $\mathrm{C}$ are chain breaking antioxidants since they react very poorly with oxygen, can be regenerated by enzymic systems, and their respective radicals are relatively harmless (Buettner, 1993). Oxidized vitamin $\mathrm{C}$ (dehydroascorbic acid) is converted back to vitamin $\mathrm{C}$ by protein disulphideisomerase (EC 5.3.4.1) and thioltransferase, also called glutaredoxin (Wells et al. 1990), 
by a reaction which results in oxidized glutathione. This provides an important metabolic link between vitamin $\mathrm{C}$ and glutathione, which plays a vital role in both detoxification (phase II) reactions (see later) and in protection against free radical mediated damage (Meister, 1991).

The properties of non-nutrient food borne antioxidants have been studied in vitro by several groups, but few have been proven to work in vivo. In assessing a potential biological antioxidant, several methods are necessary (Halliwell, 1990), and all compounds classed as antioxidants, including vitamins $\mathrm{E}$ and $\mathrm{C}$, can be pro-oxidant under certain conditions (Halliwell, 1990; Maiorino et al. 1993; Mukai et al. 1993). There are many examples in the literature of non-nutrient antioxidants (for a review see Pratt, 1992). Some examples from a long list of candidate antioxidants are carnosol and carnosic acid from the herb rosemary (Aruoma et al. 1992), caffeine (Shi et al. 1991), cinnamic acids, especially ferulic, $p$-coumaric and caffeic acids which are found in many plant foods (Howie et al. 1990; Scott et al. 1993), the flavouring agent, vanillin (Liu \& Mori, 1993), flavonoids, especially catechin, found in high concentration in tea, and quercetin, found in many plant foods (Morel et al. 1993; Scott et al. 1993), and diallyl polysulphides from 'aged' garlic extracts (Horie et al. 1992). Pro-oxidant activities of some non-nutrients have also been described. Examples include the flavour cinnamaldehyde (Raveendran et al. 1993) and carnosol/ carnosic acid (Aruoma et al. 1992).

In addition to compounds which act as antioxidants by virtue of their redox chemistry, there are also endogenous antioxidant systems (Fig. 2). These include the enzymes glutathione peroxidase (EC 1.11.1.9; Ladenstein, 1984), the $\alpha$ form of glutathione transferase (GST, EC 2.5 1. 18; Mannervik \& Danielson, 1988), glutathione reductase (EC 1.6.4.2; Chow, 1988), superoxide dismutase (EC 1.15.1.1; Hirose et al. 1993), catalase (EC 1.11.1.6; Deisseroth \& Dounce, 1970), phospholipid hydroperoxide glutathione peroxidase (Schuckelt et al. 1991), and (see Fig. 2) metal binding proteins such as ferritin and transferrin (Bomford \& Munro, 1992; Testa et al. 1993). The relative importance of some of these enzymes has been estimated (Remacle et al. 1992). In addition, there are enzymes which remove the products of free radical mediated damage such as macro-oxyproteinase and other proteinase systems, which remove damaged proteins (Pacifici \& Davies, 1990), DNA repair enzymes (see below), and the glutathione transferases and peroxidases which inactivate lipid hydroperoxides (Ladenstein, 1984; Ursini et al. 1985; Ursini \& Bindoli, 1987; Mannervik \& Danielson, 1988) and remove lipid breakdown products (Mannervik et al. 1985).

Diet exerts influence over many of these repair mechanisms (Fig. 2). For example the nutrient selenium is essential for glutathione peroxidase and phospholipid hydroperoxide glutathione peroxidase (Schrauzer, 1992) and copper, zinc and manganese are essential for synthesis of $\mathrm{CuZn}$ superoxide dismutase and $\mathrm{Mn}$ superoxide dismutase respectively (Donnelly \& Robinson, 1991). The prosthetic group of glutathione reductase is a flavin, and so dietary riboflavin is essential for the active enzyme. Indole-3-carbinol decreases the levels of superoxide dismutase and glutathione peroxidase in rat liver (Shertzer \& Sainsbury, 1991) but, with the exception of GST discussed below, generally little is known about the effect of non-nutrients on the expression of these enzymes.

\section{Alternative route to phase I metabolism - quinone reductase $(Q R)$}

$\mathrm{QR}(E C 1.6 .99 .2)$ is an enzyme which catalyses the 2-electron reduction of many quinones, without a 1-electron reduced free radical intermediate (Lind et al. 1982), and consequently there is less likelihood of free radical mediated damage (Fig. 2). Theoretically QR is able to compete with phase I enzymes for substrates, but being mainly a cytosolic enzyme its activity toward hydrophobic substrates in vivo is probably limited. The main 
isoenzyme of QR requires a flavin prosthetic group (Edwards et al. 1980), and so dietary riboflavin is essential. However, its expression is markedly influenced by many non-nutrient compounds.

A rapid and convenient assay for QR has been developed (Prochaska et al. 1985; Prochaska \& Santamaria, 1988) and a range of inducers has been identified. These include quercetin, coumarin, $\alpha$-angelicalactone (De Long et al. 1986), benzyl isothiocyanate (Talalay \& Prochaska, 1987) and sulphoraphane (Zhang et al. 1992). Extracts from many vegetables, especially brassicas, also induce QR. This is dependent on processing (Kore et al. 1993; Tawfiq et al. 1994) because endogenous plant enzymes in the vegetables break down glucosinolates into more biologically active species such as isothiocyanates (Fenwick et al. 1989). Experiments on animals have also indicated a wide range of inducers of $Q R$, such as phenethyl isothiocyanate (Guo et al. 1993), eugenol (Verhagen et al. 1993) and erucin (Zhang et al. 1992). Diet can intervene at more than one level in the induction process, including the stabilization of protein or mRNA, but it is most effective at the transcription stage. Certain inducers of $\mathrm{QR}$, including aromatic isothiocyanates and flavonoids, are known to possess blocking activity (Wattenberg, 1993).

QR is often considered as a phase II enzyme, and a unifying theory for induction of phase I and phase II enzymes has been presented (Prochaska et al. 1985), postulating that inducers fall into two classes-bifunctional (induce phase I and II enzymes) and monofunctional (induce phase II only). The former include compounds such as benzo(a)pyrene and aflatoxin (Talalay \& Prochaska, 1987). The latter include diphenols such as hydroquinone and isothiocyanates (Talalay \& Prochaska, 1987). Bifunctional inducers require activation by phase I enzymes to redox labile molecules before they are able to induce phase II enzymes. This hypothesis suggests that the redox signal is the most important for induction of $\mathrm{QR}$, but does not satisfactorily explain induction by compounds such as isothiocyanates (Daniel, 1993).

The control of QR by redox signals is via a sequence of DNA in the $5^{\prime}$ flanking region of the gene, which is called the ARE (antioxidant responsive element; Rushmore et al. 1991). Depending on the species, these responsive elements may or may not contain within them an element responsive to phorbol-12- $O$-tetradecanoate-13-acetate ( $\mathrm{Li} \&$ Jaiswal, 1992; Xanthoudakis et al. 1992; Daniel, 1993; Rushmore \& Pickett, 1993) which binds to the transcription factors fos and $j u n$. These are regulated via a protein called ref-1, which controls the redox state of sulphydryl residues, essential for DNA binding, on fos and jun (Abate et al. 1990; Xanthoudakis et al. 1992). The sulphydryl-disulphide redox state of the cell is communicated via thioredoxin. This implies that a wide range of antioxidants will influence expression of QR via thioredoxin, and indeed butylated hydroxyanisole, butylated hydroxytoluene, and ethoxyquin do affect expression (De Long et al. 1986; Derbel et al. 1993). However, there is a growing body of evidence that transcription factors other than fos and jun are involved in controlling expression (Rushmore \& Pickett, 1993). Nguyen \& Pickett (1992) have identified two transcription factors of 28000 and 45000 Daltons, that are constitutive and bind to the ARE sequence. In identifying the ARE, Pickett's group showed that this element responded to redox cycling phenolics, such as hydroquinone and catechol, but not to resorcinol which cannot redox cycle (Rushmore et al. 1991). By implication, redox cycling phenolics in the diet may affect binding to the ARE. It is clear that control of expression via the ARE is a subject for future research. Indeed, a variety of chemicals with a large range of structures is able to induce QR, and this property may correlate with their reactivity as Michael acceptors (Riley \& Workman, 1992). 


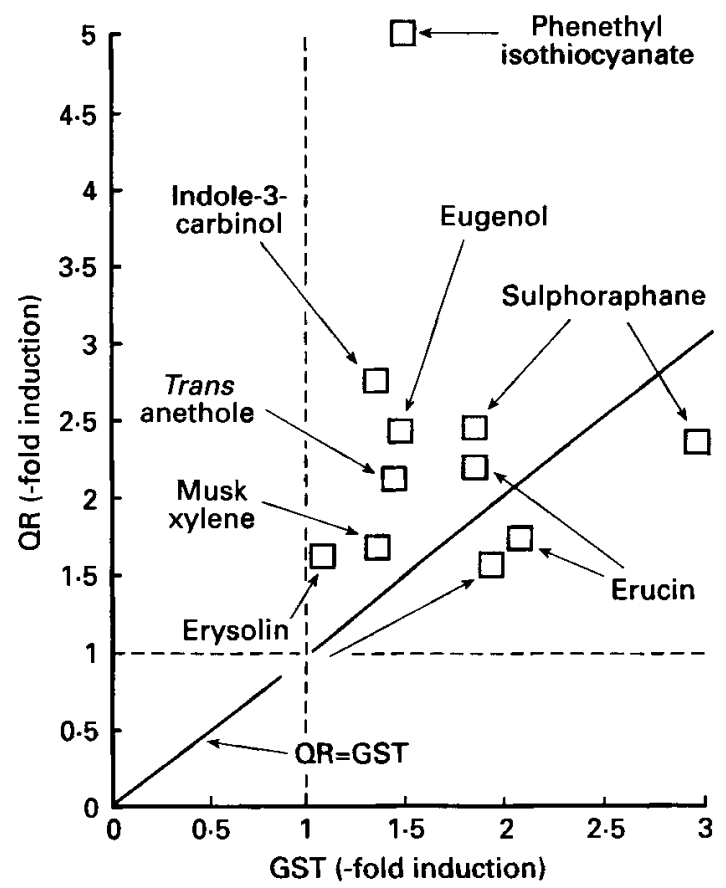

Fig. 3. Co-ordinate induction of GST and QR in animals? Induction (-fold) of GST and QR (equal induction represented by - -) is compared for several dietary compounds using animal models: sulphoraphane, erucin and erysolin in mouse liver and stomach (Zhang et al. 1992); phenethyl isothiocyanate in rat liver (Guo et al. 1993); indole-3-carbinol in rat liver (Wortelboer et al. 1992); eugenol and transanethole in rat liver (Verhagen et al. 1993); musk xylene in rat liver (Iwata et al. 1993).

\section{CONJUGATION BY PHASE II ENZYMES}

Conjugation results in a xenobiotic which is more hydrophilic, and can therefore be transported more readily out of the cell. Metabolites from the action of monooxygenase or QR reduction are conjugated with glutathione by GST, with UDP-glucuronic acid by UDPglucuronosyltransferase (UDPGT, 2.4.1.17; Mannervik, 1985; Brierley \& Burchell, 1993), with 3 '-phosphoadenosine-5'-phosphosulphate by sulphotransferases $(E C 2.8 .2 . \mathrm{x})$ or by amino acid transferases (commonly with glycine). The route of conjugation depends on the chemical nature of the compound and varies from one species to another. GST and UDPGT are the most studied systems. GST requires no nutrients as prosthetic groups, but requires glutathione as a cofactor: synthesis of glutathione requires dietary cysteine (Meister, 1991). There are a large number of isoforms of GST in humans, and all GST can be classified as $\alpha, \mu, \pi, \theta$ or microsomal (Black \& Coon, 1987; Mannervik \& Danielson, 1988; Black \& Wolf, 1991). The isoforms have individual but overlapping specificity profiles for a wide range of electrophilic carcinogens. Only GST $\alpha$ is able to reduce organic hydroperoxides (but not $\mathrm{H}_{2} \mathrm{O}_{2}$ ) and so contributes to reducing free radical mediated damage (Mannervik \& Danielson, 1988). Most of the work on control of expression of GST has been performed on animal models, and many compounds have been tested for their ability to induce GST in rats (Nijhoff et al. 1993 and Fig. 3). In one study, quercetin, flavone, ferulic acid, ellagic acid, coumarin, $\alpha$-angelicalactone and curcumin all induced GST $\alpha$ in rat liver, although in contrast to other studies (Bradfield et al. 1985) large doses of Brussels sprouts ( $20 \%$ of diet) did not. All of the above, except for quercetin and curcumin, also increased liver glutathione levels, as did Brussels sprouts (Nijhoff $e$ t al. 
1993). Although the genes have been sequenced (Klone et al. 1992; Rozen et al. 1992), control of GST $\alpha$ in humans is poorly understood. The rat and mouse $\alpha$ classes are controlled via the ARE/EpRE/TRE mechanism (EpRE, electrophile responsive element; TRE, phorbol-12- $O$-tetradecanoate 13-acetate responsive element) as described above for QR (Friling et al. 1992; Nguyen \& Pickett, 1992; Daniel, 1993), and there is some evidence for coordinate induction of GST and QR in these species (Talalay et al. 1988). Although many compounds which are inducers of QR are also inducers of GST, Fig. 3 shows that the induction is not quantitatively coordinated for a range of non-nutrient compounds. It will be very interesting to see if regulation of QR and GST are coordinately controlled in humans. Compounds with the ability to induce both QR and GST in humans would presumably exhibit potent activities as blocking agents, especially if this were combined with antioxidant properties.

UDPGT also exists as a family of enzymes (Brierley \& Burchell, 1993), again with different but overlapping specificities. The induction of UDPGT by drugs and other xenobiotics has been relatively well studied (Sutherland et al. 1993), and compounds such as dipyridyls induce UDPGT as well as GST, but not sulphotransferase in rats (Franklin, 1991). Dietary lipid affects the UDPGT activity. In a study in which rats were fed a diet supplemented with fish oil there was a 3-fold increase in UDPGT after 4 weeks compared to a control group given a fat-free diet (Dannenberg \& Yang, 1992). Cytochrome P450 1 A2 and 2E1 are also induced by fish oils (Yoo et al. 1990), and regulation of expression of UDPGT, like P450 1A1/2, is influenced by the Ah receptor (Brierley \& Burchell, 1993). Expression is also influenced by the peroxisome proliferator receptor (Brierley \& Burchell, 1993). The effect of non-nutrients on UDPGT expression has been poorly studied in humans. Subjects fed a diet high in cabbage and Brussels sprouts showed a modest increase in UDPGT (Miners \& Mackenzie, 1991). Given the wide range of drugs that induce UDPGT, it will be of interest to determine which, if any, non-nutrients affect the expression of UDPGT in humans.

In the final phase of detoxification (Phase III) glutathione conjugates are actively removed from the cell by the glutathione-S-conjugate export pump, which is dependent on ATP (Ishikawa, 1992). Some carcinogens are removed by P-glycoprotein, without the need for conjugation and this reaction also requires ATP (Ishikawa, 1992). We are unaware of any non-nutrient food constituents which influence this process.

\section{INDIRECT EFFECTS VIA ENTERIC BACTERIAL METABOLISM}

Mallett \& Rowland (1990) have pointed out that bacteria present in the gut lumen express enzymes which may influence the metabolism of xenobiotics in host tissues. For instance, when potentially carcinogenic compounds are detoxified by UDPGT (Dutton, 1980), the conjugates are secreted via the bile into the gut lumen. The activity of bacterial $\beta$-Dglucuronidase (EC 3.2.1.31; Cole et al. 1985; Gadelle et al. 1985) may result in the hydrolysis of the conjugates, and their consequent reabsorption into the circulation in their active, deconjugated form (Rowland et al. 1985). $\beta$-Glucuronidase activity has been implicated in the activation of benzo $(a)$ pyrene and 1,2-dimethylhydrazine conjugates in the colon (Nanno et al. 1986; Mallett \& Rowland, 1990). It has been demonstrated that the yield of colorectal tumours is lower in germ free rats exposed to 1,2-dimethylhydrazine than in similarly treated conventional rats (Reddy et al. 1974) and that a $\beta$-glucuronidase inhibitor can protect rats with a conventional flora from the induction of tumours by azoxymethane, a metabolite of 1,2-dimethylhydrazine (Takada et al. 1982).

Gut bacteria also express $\beta$-glycosidase activity, one of the effects of which is the liberation of biologically active flavonoid aglycones from their glycoside conjugates 
(Brown, 1988). It has been shown that the presence of the dietary flavonoid rutin (itself a substrate for $\beta$-glycosidase) in the diet of rats leads to a 20 -fold increase in the level of $\beta$ glycosidase activity in the caecum and that this is associated with changes in the ability of hepatic microsomes obtained from those rats to activate bacterial promutagens in vitro (Mallett et al. 1989). Modulation of $\beta$-glucuronidase and $\beta$-glycosidase activities in enteric bacteria remains a hypothetical blocking mechanism and in theory would remove the requirement that a compound taken orally would need to traverse the gut wall and enter the circulation in an active form in order to modulate the expression of xenobiotic metabolizing enzymes.

\section{INDUCERS OF DNA REPAIR}

Wattenberg does not include agents that modify DNA repair in his classification scheme but Morse \& Stoner (1993) classified such compounds as blocking agents. Clearly they cannot be described as suppressors for they exert their influence prior to promotion. However, they do not share the common feature of all other blocking agents, which act to prevent the occurrence of DNA lesions rather than to reduce the deleterious effects of such lesions. Furthermore, while DNA repair may be involved in the conversion of various forms of DNA damage into mutagenic lesions, and thus could be said to be involved in initiation, certain lesions such as $O^{6}$-alkylguanine adducts are thought to be capable of inducing mutations without further modification. Thus their repair could be considered a postinitiatory event. Given these complicating factors, we propose that modifiers of DNA repair should be included as a category in their own right, acting after blocking agents, as strictly defined, but prior to suppressing agents.

Much of the evidence for the existence of naturally occurring inducers of DNA repair has been obtained using prokaryotic cells. For example it has been reported that the natural flavouring vanillin can inhibit the induction of mutations in Escherichia coli by the promotion of RecA dependent recombinational repair (Ohta et al. 1986, 1988). Similar antimutagenic properties have been reported for the flavouring agents cinnamaldehyde and coumarin (Ohta et al. 1983a,b) while Shimoi et al. (1985) have reported that tannic acid, which is found in tea, protects $E$. coli from the mutagenic effects of u.v. light. The fact that protection was only conferred by tannin components (gallic acid, (-)-epicatechin gallate, (-)-epigallocatechin and (-)-epigallocatechin gallate) to $u v r^{+}$but not $u v r A^{-}$strains led them to propose that the antimutagenic activity was due to stimulation of $u v r A$ dependent excision repair (Shimoi et al. 1986).

The relevance of these findings to human nutrition may be questioned, given that prokaryotic and eukaryotic DNA repair processes are known to differ markedly in their sensitivity to modifying agents such as caffeine. However, vanillin, anisaldehyde, cinnamaldehyde and coumarin have been shown to protect $\mathrm{CHO}$ cells from the clastogenic and mutagenic effects of u.v. light and X-rays in vitro (Sasaki et al. 1990a). Vanillin has also been shown to protect CHO cells from the clastogenic effects of mitomycin C (Sasaki et al. 1987) and from the mutagenic effects of u.v. and X-rays (Imanishi et al. 1990), and has been shown to have protective activity against the induction in mice of micronuclei by mitomycin C or by X-rays (Inouye et al. 1988; Sasaki et al. 1990b) and of mutations by ethylnitrosourea (Imanishi et al. 1990). It has been proposed that vanillin promotes DNA repair via DNA nucleotidyltransferase $\beta$ (EC 2.7.7.7; Sasaki et al. 1990a). The complexity of this field is illustrated by the work of Imanishi et al. (1991) who showed that components of tea tannin can inhibit mammalian DNA repair when unmodified, but that metabolites resulting from pretreatment with a metabolically active hepatic microsome extract (S9) can actually promote excision repair activity in the same test systems. 


\section{SUPPRESSING AGENTS}

The concept of a suppressing agent was introduced by Wattenberg to account for the ability of compounds such as sodium cyanate, tert-butylisocyanate and benzyl isothiocyanate to inhibit the appearance of tumours, even when fed considerably after the chemical treatment which initiated the neoplasia (Wattenberg, 1981). Benzyl isothiocyanate is found in cruciferous vegetables, and Wattenberg's group went on to feed brassicas to rats previously treated with 7,12-dimethylbenz $(a)$ anthracene in order to test their ability to inhibit the emergence of mammary tumours. Cabbage or broccoli was fed to rats for an 18 week period, starting 1 week after cessation of treatment with the carcinogen. For both vegetables the numbers of animals with mammary tumours in the treatment group were $40 \%-50 \%$ lower than in the control groups and the average number of tumours per rat was about $60 \%$ lower (Wattenberg et al. $1989 a, b$ ). Similar observations were made for other foods including green coffee beans, green Brazilian cocoa beans and orange oil (Wattenberg, 1983). Recently many more naturally occurring suppressing agents have been identified (Wattenberg, 1993).

Any logical classification of suppressing agents must be based upon the identification of their mechanisms of action, but in most cases this is unknown. Even for the aromatic isothiocyanates, first identified as suppressing agents by Wattenberg, the mechanism of action remains uncertain and is probably multifactorial (Wattenberg, 1993). For example, Sugie et al. (1993) have reported that oral administration of benzyl isothiocyanate and benzyl thiocyanate to male F344 rats resulted in the suppression of proliferative activity in hepatocyte primary cultures derived from them. However Musk \& Johnson (1993b) have shown that aromatic isothiocyanates are selectively toxic against transformed colorectal tumour cells. Thus the same compounds may exert quite different effects at different stages of carcinogenesis. The difficulty of achieving a satisfactory classification of suppressing agents reflects our current incomplete understanding of tumour biology. By definition, suppressing agents act by inhibiting tumour promotion. In Fig. 1 we have used a simple classification which reflects the possible mechanisms whereby compounds may inhibit the progression of cells initiated by genotoxic damage.

\section{INHIBITORS OF CELL PROLIFERATION}

Cellular hyperproliferation is now recognized as a potentially important mechanism of carcinogenesis (Preston-Martin et al. 1990). Cell populations undergoing a high rate of division are more susceptible to DNA damage, both by endogenous oxidative mutagenesis and by exogenous chemical mutagens, than quiescent cells (Tong et al. 1980). Single stranded DNA is intrinsically more vulnerable to damage than double stranded, and the time available for DNA repair is reduced in rapidly proliferating cells (Ames \& Gold, 1991). Furthermore, rapid proliferation is thought to favour somatic recombination, allowing cells which are heterozygous for a mutation favouring transformation to become homozygous and give rise to neoplastic progeny (Groden et al. 1990). Somatic recombination may be an important aspect of carcinogenesis during both initiation and promotion. Environmental factors which can inhibit proliferation could therefore be classified as either blocking or suppressing agents, depending upon the tissue concerned, and the particular mechanism of carcinogenesis which is being inhibited. This illustrates once more the difficulty of fitting the growing list of food borne protective factors into any rigid system of classification. Those cellular control mechanisms that have been identified as potentially susceptible to modification by food borne protective factors will now be 
described briefly and examples will be given. In view of the incomplete understanding of promotion, the relationships between the mechanisms remain undefined and, in the case of multifunctional agents, their relative importance cannot yet be assessed.

\section{Modification of intracellular signalling}

The proliferation of normal cells is regulated by a complex system of membrane receptors and intracellular signal pathways, some of which may be susceptible to modulation by plant cell constituents derived from food. Receptor mediated hydrolysis of membrane bound phosphatidylinositol-4,5-biphosphate yields two intracellular second messengers, inositol 1,4,5-triphosphate and 1,2-diacylglycerol. This sequence of events forms part of a signal transduction pathway which is involved in the regulation of cellular proliferation in a range of mammalian tissues (Berridge \& Irvine, 1984). Under normal circumstances, release of 1,2-diacylglycerol leads to activation of protein kinase C (PKC, EC 2.7.1.37), a step which is known to stimulate cell proliferation by mechanisms which include activation of ornithine decarboxylase (ODC), while inositol 1,4,5-triphosphate mobilizes intracellular calcium.

Inositol hexaphosphate, usually referred to as phytate, is widely distributed in plant foods and is present at particularly high levels in cereals and legume seeds. It has been proposed that the supposed anticarcinogenic properties of diets rich in cereals may be due to the presence of phytate rather than dietary fibre, and evidence for a protective effect of isolated inositol hexaphosphate has been obtained in animal experiments (Shamsuddin \& Sakamoto, 1992). When the compound was administered orally to rats 2 weeks or 5 weeks after treatment with the chemical carcinogen azoxymethane, a significant reduction was observed in the number of animals with tumours and the number and size of tumours in the affected animals (Shamsuddin \& Ullah, 1989). This is strong evidence to suggest that exogenous inositol hexaphosphate can function as a suppressing agent, perhaps by entering and modifying the inositol phosphate metabolism pathways of the cell. Further work will be needed to clarify the mechanisms involved and assess the significance in relation to the human diet.

The direct inhibition of PKC might also provide a mechanism for suppression as stimulation of PKC leads to the activation of proteins that affect cellular proliferation (Blumberg, 1988). Glycyrrhetic acid is a breakdown product of glycyrrhizin, a sweet constituent of licorice. This compound has been demonstrated both to inhibit PKC (O'Brian et al. 1990) and to possess antitumorigenic activity, preventing the inflammatory and toxic effects of 12-O-tetradecanoylphorbol-13-acetate (Wang et al. 1991; Nishino, 1992). PKC may also be involved in the control of intercellular communication in that tumour promoters which have been shown to activate PKC have also been demonstrated to inhibit the transfer of fluorescent dye between adjacent cells in culture (Enomoto \& Yamasaki, 1985). It has been proposed that compounds that inhibit such communication may function as tumour promoters by interfering with cell-cell growth regulatory mechanisms and thereby encouraging cellular replication (Trosko \& Chang, 1984). Epidemiological evidence suggests that green tea may be protective against cancer (Oguni et al. 1989). An extract of green tea consisting largely of various catechins (Maeda \& Nakagawa, 1977) previously shown to possess antimutagenic and anticarcinogenic properties (Cheng et al. 1986; Ruch et al. 1989) apparently prevents the inhibition of intercellular communication induced in cultured mammalian cells by the promoters phenobarbital and 12-O-tetradecanoylphorbol-13-acetate (Ruch et al. 1989).

Proteinase inhibitors have been reported to suppress tumour promotion in rodents at a variety of sites including skin, colon, breast and liver (Yavelow et al. 1983; Troll et al. 1984, 1992; Billings et al. 1990). They inhibit the transformation of mammalian cells in vitro by 
radiation and by oncogenes (Kennedy \& Little, 1981; Yavelow et al. 1983, 1985; Garte et al. 1987) and inhibit the production of oxygen radicals by tumour promoters (Frenkel et al. 1987; Troll et al. 1987). Troll et al. (1992) have proposed that proteinase inhibitors might exert their antitumorigenic effect by inhibiting the proteolytic modification of PKC which is necessary for its activation as a tumour promoter (Murray et al. 1987). Many experiments using proteinase inhibitors have involved the topical application of inhibitors to skin. However, it has been demonstrated that inclusion of a soyabean extract containing the Bowman-Birk proteinase inhibitor in the diet can protect mice against the induction of lung tumours by 3-methylcholanthrene (Witschi \& Kennedy, 1989) and against induction of colonic adenomas by 1,2-dimethylhydrazine (Weed et al. 1985). Furthermore, epidemiological evidence suggests that diets containing high levels of foods rich in proteinase inhibitors are protective against cancers of the breast, colon and prostate (Correa, 1981). It has been proposed by Schelp \& Pongpaew (1988) that chemoprevention may be possible by a nutritionally induced increase in the production of endogenous inhibitors.

\section{Inhibition of oncogene expression}

The progressive loss of proliferative control which characterizes cellular transformation is accompanied by an accumulation of acquired genetic defects involving proto-oncogenes, many of which code for proteins involved in the regulation of cell proliferation. One mechanism by which dietary agents might suppress promotion is by inhibiting the posttranslational modification of oncoproteins. For example the ras family of proto-oncogenes code for a group of small guanosine 5 -triphosphatases, including $\mathrm{p} 21^{\text {ras }}$, which regulate various aspects of cellular growth and differentiation. Ras mutations are associated with many types of tumour. To exert its transforming properties the mutated $\mathrm{p} 21^{\text {ras }}$ must be translocated to the plasma membrane, and for this to occur it must undergo farnesylation (Casey et al. 1989; Kato et al. 1992). Limonene is a monoterpene component of orange peel oil which inhibits the development of mammary carcinomas at the promotional stage of induction by the carcinogen 7,12-dimethylbenz( $a$ )anthracene in the rat (Elegbede et al. 1986) and has also demonstrated antitumorigenic properties in a murine model (Wattenberg et al. $1989 \mathrm{~b}$ ). It has been proposed that the antitumorigenic properties of $d$-limonene reflect its ability to reduce the farnesylation of $\mathrm{p}^{2} 1^{\mathrm{ras}}$ (Crowell et al. 1991). Although exposure to other monoterpenes has been shown to bring about a decrease in expression of an enzyme involved in the synthesis of farnesyl moieties (3-hydroxy-3-methylglutaryl coenzyme A reductase; EC 1.1.1.88) in the liver of rats (Clegg et al. 1982), this reduction does not seem to play a role in influencing the farnesylation of $\mathrm{p} 21^{\text {ras }}$ (Crowell et al. 1991). This mechanism may be relevant to other aspects of cellular control mediated by isoprenylated proteins. It is interesting to note that limonene is one example of a substance which, though it is capable of suppressing tumorigenesis in certain models, can also be shown to be carcinogenic in other circumstances. In this instance, the induction of kidney tumours in the rat by limonene appears to be species and sex specific (Dietrich \& Swenberg, 1991).

\section{Polyamine metabolism}

The intracellular level of polyamines plays a central role in the control of proliferation (Williams-Ashman \& Canellakis, 1979; Pegg, 1988). Tumour promoters such as 12-Otetradecanoylphorbol-13-acetate have been found to increase the activity of ODC, which catalyses the formation of the polyamine precursor putrescine from ornithine (McCann et al. 1992), and so increases the concentration of polyamines in affected tissues (Slaga, 1983). It has been demonstrated that an increase in ODC activity and polyamine levels is an 
absolute requirement for the proliferation of a variety of human tumour cells both in vitro and in vivo (Luk, 1992), and inhibitors of ODC have been shown to deplete polyamine levels and block proliferation in cultured cells (Mamont et al. 1976) and in tumours in vivo (Pegg, 1988). It has been proposed that the ability of the flavonoid apigenin to suppress skin tumorigenesis in mice, and of curcumin, a constituent of turmeric, to suppress early markers of tumorigenesis in the rat colon, may be related to reduced ODC levels in the target tissues (Wei et al. 1990; Rao et al. 1993). Other flavonoids that have been reported to inhibit promoter induced increases in ODC include kaempferol, luteolin, morin and fisetin (Nakadate et al. 1984; Fujiki et al. 1986).

Inhibition of arachidonic acid metabolism is closely linked to the direct inhibition of ODC. Increased metabolism of arachidonate is commonly seen in experimental models of tumour promotion (Earnest et al. 1992). Both the cyclo-oxygenase and the lipoxygenase (EC 1.13.11.12) pathways of arachidonic acid metabolism (Moncada et al. 1980) are implicated in this promoting effect, which may operate via the up-regulation of ODC activity (Yamamoto \& Kato, 1992). Blocking the metabolism of arachidonate has been shown to inhibit the growth of human cells both in vitro and in vivo (Levine et al. 1972; Hial et al. 1977; Bayer et al. 1979; Sato et al. 1983; Goodlad et al. 1989). Curcumin, an inhibitor of promotion induced by croton oil and 12-O-tetradecanoylphorbol-13-acetate in the murine skin model (Huang et al. 1988; Soudamini \& Kuttan, 1989), has been shown to inhibit the activities of cyclo-oxygenases and lipoxygenases (Huang et al. 1991; Rao et al. 1993). The ability of the flavonoids quercetin, fisetin, kaempferol and morin to suppress promotion (Kato et al. 1983; Nakadate et al. 1984) may correlate with their ability to inhibit lipoxygenase (Nakadate et al. 1984).

\section{Oestrogen metabolism}

Certain tumour types are responsive to oestrogens and this presents another mechanism by which promotion could theoretically be inhibited. $16 \beta$-Hydroxyoestrone functions as a promoter of mammary cell transformation (Telang et al. 1992) and enhances the expression of oncogenes in human cancer cells (Hsu et al. 1991), whilst 2-hydroxyoestrone is antioestrogenic in cell culture (Schneider et al. 1984). Thus the induction of enzymes that increase the 2-hydroxylation of oestrogens, relative to their $16 \beta$-hydroxylation, may be anticarcinogenic (Jellinck et al. 1993). Such induction has been reported in mouse and rat liver following feeding with indole-3-carbinol, which, as we have seen, is derived from cruciferous vegetables (Baldwin \& LeBlanc, 1992; Jellinck et al. 1993). In human volunteers the rate of 2-hydroxylation of oestradiol in an in vivo radiometric assay was increased by $50 \%$ after daily exposure to $6-7 \mathrm{mg}$ indole-3-carbinol $/ \mathrm{kg}$ for $7 \mathrm{~d}$ and the urinary excretion of 2-hydroxyoestrone was increased relative to that of oestriol (Michnovicz \& Bradlow, 1990, 1991). Indole-3-carbinol forms condensation products under acid conditions; the ability of these products to induce similar effects to indole-3-carbinol and the inactivity of the parent compound when administered intraperitoneally has led to the suggestion that the condensation products formed in the acid milieu of the stomach might be the active moieties in this induction (Bradfield \& Bjeldanes, 1991).

Caffeine has been shown to reduce the number of mammary tumours induced in mice by a combination of $17 \beta$-oestradiol and progesterone (VanderPloeg \& Welsch, 1991). In other studies however, caffeine has been shown to enhance the development of mammary tumours in mice, spontaneous or induced by 7,12-dimethylbenz(a)anthracene (Nagasawa \& Konishi, 1988; Welsch et al. 1988), and to enhance the development of pancreatic tumours in hamsters exposed to $N$-nitroso-bis-(2-oxopropyl)amine at a postinitiation stage (Nishikawa et al. 1992). The mechanism(s) by which caffeine exerts its effects remain a matter for conjecture, though Alldrick \& Rowland (1988) have demonstrated that it can 
inhibit the ability of mouse hepatic microsomes to metabolize 2-amino-3,4-dimethylimidazo[4,5-f]quinoline, Trp-P-2 and 2-amino-3,8-dimethylimidazo[4,5-f]quinoxaline to bacterial mutagens and Welsch et al. (1988) have observed an enhancing effect of caffeine on the responsiveness of murine mammary organ cultures to mammotrophic growth hormone.

Human blood, faeces and urine commonly contain varying quantities of oestrogenic compounds derived from precursors found in plant foods. Lignans are compounds with a dibenzylbutane structure that were first identified as secondary metabolites of plants. The two most important mammalian lignans, enterodiol and enterolactone, are derived from lignans of plant origin by the activity of bacteria in the alimentary tract (Axelson et al. 1982). Isoflavonoids are a group of plant diphenols, of which many have oestrogenic activity. They occur extensively in plants used as human foods, and many of them have been detected in human and animal urine. These compounds include equol, methylequol, daidzen, dihydrodaidzen, 3',7-dihydroxyisoflavan and others (Adlercreutz, 1990).

The mammalian lignans and the isoflavonoids exhibit weak oestrogen-like activity, together with a variety of other physiological activities including antiproliferative effects and cytotoxicity (Setchell \& Adlercreutz, 1988). Many of these effects are apparently mediated via the interaction of phyto-oestrogens with mammalian oestrogen receptors. For example lignans and isoflavonoids compete with endogenous oestrogens for type II oestrogen binding sites and may thereby regulate the growth of oestrogen dependent tissues (Markaverich et al. 1988). A second important effect of these compounds is the stimulation of endogenous production of sex hormone binding globulin (SHBG) which modulates the biological activity of oestrogen in humans. Adlercreutz and co-workers have observed that enterolactone causes a dose dependent stimulation of SHBG synthesis in HepG2 cells in culture. A positive relationship between plasma SHBG levels and urinary lignan and isoflavonoid excretion in humans has also been observed, and ascribed to stimulation of hepatic SHBG synthesis by dietary phyto-oestrogens (Adlercreutz et al. 1993).

Epidemiological evidence can be interpreted in favour of a protective role for the phytooestrogens against sex hormone dependent tumours, principally carcinoma of the breast and prostate cancer. Urinary excretion of these compounds is reported to be higher in vegetarians than in omnivores, and lower in breast cancer patients. Japanese women consuming a traditional diet have both a low incidence of breast cancer and a relatively low mortality from this disease (Nomura et al. 1978), and Japanese men experience relatively low mortality from prostate cancer, although the incidence of this common but often slow growing tumour is apparently similar to that of western populations. Adlercreutz et al. (1991) proposed that the slow growth of both breast and prostate cancers in Japanese patients consuming traditional diets may be due to inhibitory effects of isoflavanoids derived primarily from soya products. This proposal is supported by the observation that a high intake of soya products is associated with reduced risk of breast cancer amongst women in Singapore (Lee et al. 1991), but there is little direct experimental evidence for the putative mechanism.

\section{DIRECT ACTING MODULATORS OF CELL DAMAGE}

\section{Suppression of free radical production}

Oxidative damage by free radicals appears to be important at the promotion stage as well as the initiation stages of carcinogenesis discussed earlier. Many food borne compounds that can inhibit the generation of oxidative damage may exert an antipromotional effect. For example epigallocatechin gallate, which is found in teas, has been shown to reduce both 
the induction of lung tumours, and the formation of 8-hydroxydeoxyguanosine (a marker for oxidative DNA damage) in mouse lung tissue exposed to 4-(methylnitrosamino)-1-(3pyridyl)-1-butanone, without having any effect on the initial level of alkylation in the DNA (Xu et al. 1992). It has also shown antipromoter activity in skin, duodenum and liver (Fujiki et al. 1992). The catechin-rich extract of green tea referred to above as an inhibitor of intercellular communication has also been shown to protect cultured cells against cytotoxicity induced by oxygen radicals (Ruch et al. 1989).

\section{Selective cytotoxins}

Chemotherapy and radiotherapy involve exposure to high levels of cytotoxic agents with the aim of inhibiting the growth of tumour cells and ultimately of killing them. Ideally therapeutic agents would be, if not absolutely specific for tumour cells, then at least highly selective in their mode of action. It is not conceivable that the human diet normally contains biologically significant concentrations of cytotoxic agents of a similar nonspecificity to commonly used therapeutic agents but many secondary plant metabolites are cytotoxic, and some of these compounds may selectively target tumours or precancerous cells.

Evidence for selective toxicity against transformed cells has been presented for polyunsaturated fatty acids (Bégin et al. 1986), and also for the compounds 1-cyano-2hydroxy-3-butene, which is found in cruciferous vegetables (Wallig et al. 1993) and quercetin (Larocca et al. 1991), the latter having been shown to be active in vivo (Castillo et al. 1989). We have recently shown that the dietary compound allyl isothiocyanate, again derived from cruciferous vegetables and a major constituent of mustard, is more toxic towards transformed HT29 human colorectal adenocarcinoma cells than towards cells which have been experimentally detransformed in vitro (Musk \& Johnson, 1993a). A similar selective effect of quercetin has also been observed (S. R. R. Musk \& I. T. Johnson, unpublished observations). It will clearly be of interest to determine whether other dietary compounds with demonstrated cytotoxic activity (Mori et al. 1988; Babich et al. 1993) might also be selective and if so, whether such compounds might have a practical role to play as food borne protective factors in chemoprevention, or as chemotherapeutic agents.

\section{INDUCERS OF CELLULAR DIFFERENTIATION}

Tumour promoters are known to influence cell differentiation, either by inhibiting normal differentiation or by inducing inappropriate differentiation programmes (Yamasaki, 1984). The second class of suppressing agent comprises compounds which act by modulating the differentiation of tumorous or pretumorous cells, thereby slowing or even halting their growth. Retinoids, calcium and vitamin $\mathrm{D}$ have been shown to modify cell differentiation both in vitro and in vivo (Lotan $1992 a$; Moon et al. 1992), and to exert antipromotive effects in animal models of tumorigenesis (Lotan, 1980; Dawson \& Okamura, 1990) although it has also been proposed that these compounds may act by modifying the expression of ODC (Dawson et al. 1987) or by enhancing intercellular communication (Hossain et al. 1989). Certain dietary carotenoids such as astaxanthin, canthaxanthin and fucoxanthin, which do not demonstrate provitamin A activity in mammals, are known to exhibit anticarcinogenic properties in animal models (Mathews-Roth, 1982; Grubbs et al. 1991; Okuzumi et al. 1993; Tanaka et al. 1994). An effect on differentiation remains a theoretical mode of action for these compounds. Fucoxanthin suppressed the growth of, and expression of $\mathrm{N}-m y c$ in, tumour cells in vitro (Okuzumi et al. 1990) and canthaxanthin inhibited the growth of tumour cells and the transformation of 10T1/2 cells (Pung et al. 1988; Huang et al. 1992). 


\section{ANTIMETASTATIC AGENTS}

The final stages of epithelial tumorigenesis involve invasion of the basal lamina by fully transformed cells and migration, via the blood or lymph systems, to new tissue sites where secondary tumours can develop. Bracke et al. (1989) have reported that the invasive behaviour of $\mathrm{MO}_{4}$ cells (fetal mouse cells transformed with Kirsten murine sarcoma virus) towards embryonic chick heart fragments in vitro can be greatly reduced by exposure of the cultures to the flavonoid tangeretin. Inhibition was noticeable at a concentration of $0.01 \mathrm{~mm}$ and was completely reversible after removal of the tangeretin. Similar observations have been reported for another flavonoid, (+)-catechin (Bracke et al. 1984, 1987) and for retinoids (Lotan, 1992b). Such an effect might contribute to the inhibitory action of dietary cabbage on the yield of pulmonary metastases in mice injected with BALB/c tumour cells (Scholar et al. 1989). Thus dietary components may modify the carcinogenic process even after the completion of promotion.

\section{IMMUNOMODULATION}

Certain compounds that possess antitumorigenic properties have also been shown to enhance the immune response. Examples include $\beta$-carotene and the carotenoids canthaxanthin and astaxanthin (Bendich \& Shapiro, 1986; Jyonouchi et al. 1991, 1993). It has been proposed that the antitumorigenic action of these compounds may be causally linked to their immunoenhancing properties (Shklar \& Schwartz, 1988; Bendich, 1989). Given that high levels of prostaglandins $E_{1}, E_{2}, A_{1}$ and $A_{2}$ have been shown to suppress the killing of tumour cells by natural killer cells and that inhibitors of prostaglandin synthesis can restore natural killer functions to mice with experimentally depressed activity (Brunda et al. 1980; Taffet \& Russell, 1981), it is also possible that inhibitors of arachidonic acid metabolism might exert an antitumour effect via this mechanism (Goodwin, 1984).

\section{A NEW CLASS OF NUTRIENTS?}

Clearly, a variety of biologically active constituents other than those conventionally recognized as nutrients may contribute to the protective effects of diets rich in fruits and vegetables against cancer. There is still much to be done to clarify the mechanisms by which plant constituents act, and there is an urgent need to assess their relative importance so that the practical implications for human diets can be properly assessed. Although an unprecedented variety of plant foods is now available to modern western consumers, the bulk of fruit and vegetable consumption involves relatively few species and varieties. Moreover the varieties most readily available tend to be determined by commercial factors related to agricultural production and distribution. It is inevitable that the increasing application of molecular biology will lead to the manipulation of food crops to improve pest resistance, yield, keeping qualities and flavour. The implications for health of such trends can only be assessed if the ensuing compositional changes and their biological significance are properly understood.

One obvious practical issue which must be addressed is the balance of risk and benefit conferred by the consumption of compounds which in many cases express more than one type of potent biological activity. Many of the substances that we have described as potential anticarcinogens have also been shown to possess potentially hazardous properties. For example, indole-3-carbinol has been shown to promote carcinogenesis in certain models (Pence et al. 1986; Bailey et al. 1987) and its toxicology will need to be thoroughly 
Table 1. Examples of dietary anticarcinogens with genotoxic or tumorigenic effects

\begin{tabular}{|c|c|c|}
\hline Compound & Assay & Reference \\
\hline Allyl isothiocyanate & Positive in Ames test & Yamaguchi, 1980 \\
\hline Allyl isothiocyanate & Induction of aberrations in mammalian cells & Kasamaki et al. 1982 \\
\hline Allyl isothiocyanate & Induction of bladder tumours by feeding & Dunnick et al. 1982 \\
\hline Allyl isothiocyanate & Transformation of mammalian cells & Kasamaki et al. 1987 \\
\hline Anisaldehyde & Induction of aberrations in mammalian cells & Kasamaki et al. 1982 \\
\hline Benzyl isothiocyanate & Positive in Ames test & Yamaguchi, 1980 \\
\hline Benzyl isothiocyanate & Induction of aberrations in mammalian cells & Musk \& Johnson, $1993 b$ \\
\hline Benzyl isothiocyanate & Induction of SCE in mammalian cells & Musk \& Johnson, $1993 b$ \\
\hline trans $\mathrm{r}$-Cinnamaldehyde & Induction of aberrations in mammalian cells & Kasamaki et al. 1982 \\
\hline trans $\mathrm{r}$-Cinnamaldehyde & Transformation of mammalian cells & Kasamaki et al. 1987 \\
\hline Coumarin & Induction of bile duct tumours by feeding & Griepentrog, 1973 \\
\hline Curcumin & Induction of aberrations in mammalian cells & Ishidate et al. 1988 \\
\hline Diallyl sulphide & Enhancement of DEN induced hepatocarcinogenesis & Takahashi et al. 1992 \\
\hline Indole-3-carbinol & Promotion of $\mathrm{AFB}_{1}$ induced carcinogenesis & Bailey et al. 1987 \\
\hline Indole-3-carbinol & Enhancement of DMH induced carcinogenesis & Pence et al. 1986 \\
\hline Kaempferol & Induction of mutations in mammalian cells & Maruta et al. 1979 \\
\hline Phenethyl isothiocyanate & Induction of aberrations in mammalian cells & Musk \& Johnson, $1993 b$ \\
\hline Phenethyl isothiocyanate & Induction of SCE in mammalian cells & Musk \& Johnson, $1993 b$ \\
\hline Quercetin & Positive in Ames test and SOS chromotest & Rueff et al. 1992 \\
\hline Quercetin & Induction of aberrations in mammalian cells & Ishidate et al. 1988 \\
\hline Quercetin & Induction of recombination in mammalian cells & Suzuki et al. 1991 \\
\hline Tannic acid & Induction of liver tumours by s.c. administration & Korpássy \& Mosonyi, 1950 \\
\hline Vanillin & Induction of aberrations in mammalian cells & Jansson \& Zech, 1987 \\
\hline Vanillin & Induction of SCE in mammalian cells & Jansson \& Zech, 1987 \\
\hline
\end{tabular}

studied before an increase in its consumption can be recommended (Bradfield \& Bjeldanes, 1991). Other examples of mutagenic, clastogenic, carcinogenic and cocarcinogenic effects of dietary constituents previously referred to are given in Table 1 . Clearly the message of epidemiology is that vegetables and fruits are overwhelmingly beneficial in their effects, but the prospect of manipulating the composition of commercial varieties inevitably raises issues of safety. It remains unclear whether any of the compounds which have been identified experimentally as potential anticarcinogens would represent a real hazard to humans if their intake were increased, but the caveat of Bradfield \& Bjeldanes (1991) regarding the need for a thorough investigation of the toxicology of indole-3-carbinol should be extended to the other putatively anticarcinogenic agents.

Can it be argued that any of the biologically active substances discussed in this review should be classified as micronutrients? The Oxford English Dictionary defines a nutrient simply as a substance serving as nourishment. To nourish is "to supply (a thing) with whatever is necessary to promote its growth or formation or to maintain it in proper condition". The last part of this definition would certainly encompass the prevention of cancer, but nutritional science tends to regard nutrients more narrowly as substances which are essential in the sense that a specific deficiency disease results if they are absent from the diet. It is improbable that any of the biologically active substances discussed here meet this criterion, but it is conceivable that human beings have become adapted to a cocktail of food borne plant metabolites which help to maintain resistance to neoplasia. The fact that many of these compounds are potentially toxic if consumed above a threshold dose need not necessarily preclude their classification as nutrients. At first sight this is something of a paradox but several recognized micronutrients have been shown to be mutagenic under appropriate conditions in vitro (Chow, 1990). 
Although human beings are highly adaptable omnivores, it is reasonable to assume that a high intake of fruits and vegetables is a biological norm. Hunter-gathering has probably been the dominant means of food provision throughout most of human evolutionary history. Modern hunter gatherers obtain more than half of their food energy from plant sources (Lee, 1967) and it has been calculated that even in industrialized societies human beings are exposed to about $1.5 \mathrm{~g}$ of potentially toxic plant constituents/d (Ames \& Gold, 1990). Many of these compounds are themselves mutagenic, and may be carcinogenic at high doses. Natural selection has probably ensured that the chemical defence mechanisms of the human body are both highly effective and inducible (Ames \& Gold, 1991). It would then follow that the maintenance of such defence mechanisms is a normal, diet dependent physiological function, and it may be appropriate to regard the constant provision of the necessary food borne factors as an aspect of normal nutrition. If this hypothesis survives further rigorous research it will be necessary to recognize the existence of a class of dietary substances which, although distinct from micronutrients defined in the conventional sense, are necessary for the maintenance of optimum health. The term 'dietary phytoprotectants' may be suitable as a collective term for such substances.

\section{REFERENCES}

Abate, C., Patel, L., Rauscher, F. J. \& Curran, T. (1990). Redox regulation of fos and jun DNA binding activity in vitro. Science 249, 1157-1161.

Adlercreutz, H. (1990). Western diet and Western diseases. Some hormonal and biochemical mechanisms and associations. Scandinavian Journal of Clinical and Laboratory Investigation 50, Suppl. 201, 3-23.

Adlercreutz, H., Carson, M., Mousavi, Y., Palotie, A., Booms, S., Loukovaara, M., Mäkelä, T., Wähälä, K., Brunow, G. \& Hase, T. (1993). Lignans and isoflavanoids of dietary origin and hormone-dependent cancer. In Food and Cancer Prevention: Chemical and Biological Aspects, pp. 348-352 [K. W. Waldron, I. T. Johnson \& G. R. Fenwick, editors]. Cambridge: Royal Society of Chemistry.

Adlercreutz, H., Honjo, H., Higashi, H., Fotsis, T., Hamalainen, E., Hasegawa, T. \& Okada, H. (1991). Urinary excretion of lignans and isoflavanoid phytoestrogens in Japanese men and women consuming a traditional Japanese diet. American Journal of Clinical Nutrition 54, 1093-1100.

Alldrick, A. J. \& Rowland, I. R. (1988). Caffeine inhibits hepatic-microsomal activation of some dietary genotoxins. Mutagenesis 3, 423-427.

Ames, B. N. \& Gold, L. S. (1990). Chemical carcinogenesis: too many rodent carcinogens. Proceedings of the National Academy of Sciences, USA 87, 7772-7776.

Ames, B. N. \& Gold, L. S. (1991). Mitogenesis, mutagenesis and rodent cancer tests. In Origins of Human Cancer: a Comprehensive Review, pp. 125-135 [J. Brugge, T. Curran, E. Harlow and F. McCormick, editors]. New York: Cold Spring Harbor Laboratory Press.

Aruoma, O. I., Halliwell, B., Aeschbach, R. \& Loligers, J. (1992). Antioxidant and pro-oxidant properties of active rosemary constituents - carnosol and carnosic acid. Xenobiotica 22, 257-268.

Aust, S. D., Morehouse, L. A. \& Thomas, C. E. (1985). Role of metals in oxygen radical reactions. Journal of Free Radicals in Biology and Medicine 1, 3-25.

Axelson, M., Sjövall, J., Gustafsson, B. E. \& Setchell, K. D. R. (1982). Origin of lignans in mammals and identification of a precursor from plants. Nature 298, 659-660.

Babich, H., Borenfreund, E. \& Stern, A. (1993). Comparative cytotoxicities of selected minor dietary nonnutrients with chemopreventive properties. Cancer Letters 73, 127-133.

Bailey, G. S., Hendricks, J. D., Shelton, D. W., Nixon, J. E. \& Pawlowski, N. E. (1987). Enhancement of carcinogenesis by the natural anticarcinogen indole-3-carbinol. Journal of the National Cancer Institute 78, 931-934.

Baldwin, W. S. \& LeBlanc, G. A. (1992). The anti-carcinogenic plant compound indole-3-carbinol differentially modulates P450-mediated steroid hydroxylase activities in mice. Chemico-Biological Interactions 83, $155-169$.

Bayer, B. M., Kruth, H. S., Vaughan, M. \& Beaven, M. A. (1979). Arrest of cultured cells in the $G_{1}$ phase of the cell cycle by indomethacin. Journal of Pharmacology and Experimental Therapeutics 210, 106-111.

Bégin, M. E., Ells, G., Das, U. N. \& Horrobin, D. F. (1986). Differential killing of human carcinoma cells supplemented with n-3 and n-6 polyunsaturated fatty acids. Journal of the National Cancer Institute 77, 1053-1062.

Bendich, A. (1989). Carotenoids and the immune response. Journal of Nutrition 119, 112-115.

Bendich, A. \& Shapiro, S. S. (1986). Effect of $\beta$-carotene and canthaxanthin on the immune responses of the rat. Journal of Nutrition 116, 2254-2262. 
Berridge, M. J. \& Irvine, R. F. (1984). Inositol triphosphate, a novel second messenger in cellular signal transduction. Nature 312, 315-321.

Billings, P. C., Newberne, P. M. \& Kennedy, A. R. (1990). Protease inhibitor suppression of colon and anal gland carcinogenesis induced by dimethylhydrazine. Carcinogenesis 11, 1083-1086.

Black, S. D. \& Coon, M. J. (1987). P-450 cytochromes: structure and function. Advances in Enzymology 60, 35-87.

Black, S. M. \& Wolf, C. R. (1991). The role of glutathione-dependent enzymes in drug resistance. Pharmacology and Therapeutics 51, 139-154.

Block, G., Patterson, B. \& Subar, A. (1992). Fruit, vegetables, and cancer prevention. A review of the epidemiological evidence. Nutrition and Cancer 18, 1-29.

Blumberg, P. M. (1988). Protein kinase C as the receptor for the phorbol ester tumor promoters: sixth Rhoads Memorial Award lecture. Cancer Research 48, 1-8.

Bomford, A. B. \& Munro, H. N. (1992). Ferritin gene expression in health and malignancy. Pathobiology 60, $10-18$.

Bowry, V. W., Ingold, K. U. \& Stocker, R. (1992). Vitamin E in human low-density lipoprotein-when and how this antioxidant becomes a pro-oxidant. Biochemical Journal 288, 341-344.

Bracke, M. E., Castronovo, V., Van Cauwenberge, R. M. L., Coopman, P., Vakaet, L., Strojny, P., Foidart, J.-M. \& Mareel, M. M. (1987). The anti-invasive flavonoid (+)-catechin binds to laminin and abrogates the effect of laminin on cell morphology and adhesion. Experimental Cell Research 173, 193-205.

Bracke, M. E., Van Cauwenberge, R. M.-L. \& Mareel, M. M. (1984). (+)-Catechin inhibits the invasion of malignant fibrosarcoma cells into chick heart in vitro. Clinical and Experimental Metastasis 2, 161-170.

Bracke, M. E., Vyncke, B. M., Van Larebeke, N. A., Bruyneel, E. A., De Bruyne, G. K., De Pestel, G. H., De Coster, W. J., Espeel, M. F. \& Mareel, M. M. (1989). The flavonoid tangeretin inhibits invasion of $\mathbf{M O}_{4}$ mouse cells into embryonic chick heart in vitro. Clinical and Experimental Metastasis 7, 283-300.

Bradfield, C. A. \& Bjeldanes, L. F. (1991). Modification of carcinogen metabolism by indolylic autolysis products of Brassica oleraceae. In Nutritional and Toxicological Consequences of Food Processing, pp. 153-163 [M. Friedman, editor]. New York: Plenum Press.

Bradfield, C. A., Chang, Y. \& Bjeldanes, L. F. (1985). Effects of commonly consumed vegetables on hepatic xenobiotic metabolising enzymes in the mouse. Food and Chemical Toxicology 23, 899-904.

Brady, J. F., Ishizaki, H., Fukuto, J. M., Lin, M. C., Fadel, A., Gapac, J. M. \& Yang, C. S. (1991). Inhibition of cytochrome P-450 2E1 by diallyl sulfide and its metabolites. Chemical Research in Toxicology 4, 642-647.

Brierley, C. H. \& Burchell, B. (1993). Human UDP-glucuronosyl transferases - chemical defence, jaundice and gene therapy. Bioessays 15, 749-754.

Brown, J. P. (1988). Hydrolysis of glycosides and esters. In Role of the Gut Flora in Toxicity and Cancer, pp. 109-144 [I. R. Rowland, editor]. London: Academic Press.

Brunda, M. J., Herberman, R. B. \& Holden, H. T. (1980). Inhibition of murine natural killer cell activity by prostaglandins. Journal of Immunology 124, 2682-2687.

Buettner, G. R. (1993). The pecking order of free radicals and antioxidants - lipid peroxidation, alpha-tocopherol, and ascorbate. Archives of Biochemistry and Biophysics 300, 535-543.

Casey, P. J., Solski, P. A., Der, C. J. \& Buss, J. E. (1989). p21 ras is modified by a farnesyl isoprenoid. Proceedings of the National Academy of Sciences, USA 86, 8323-8327.

Castillo, M. H., Perkins, E., Campbell, J. H., Doerr, R., Hassett, J. M., Kandaswami, C. \& Middleton, E. (1989). The effects of the bioflavonoid quercetin on squamous cell carcinoma of head and neck origin. American Journal of Surgery 158, 351-355.

Castillo, T., Koop, D. R., Kamimura, S., Triadafilopoulos, G. \& Tsukamoto, H. (1992). Role of cytochrome-P$4502 \mathrm{E} 1$ in ethanol-dependent, carbon tetrachloride-dependent and iron-dependent microsomal lipid peroxidation. Hepatology 16, $992-996$.

Cheng, S.-J., Ho, C.-T., Lou, H.-Z., Bao, Y.-D., Jian, Y.-Z., Li, M.-H., Gao, Y.-N., Zhu, G.-F., Bai, J.-F., Guo, S.-P. \& $\mathrm{Li}, \mathrm{X}$.-Q. (1986). A preliminary study on the antimutagenicity of green tea antioxidants. Acta Biologiae Experimentalis Sinica 19, 427-431.

Chow, C. K. (1988). Interrelationships of cellular antioxidant defense systems. In Cellular Antioxidant Defense Mechanisms, vol. 2, pp. 217-237 [C. K. Chow, editor]. Boca Raton, FL: CRC Press.

Chow, C. K. (1990). Mutagenesis and micronutrients relationship. Food Additives and Contaminants 7, Suppl. 1, S44-S47.

Clegg, R. J., Middleton, B., Bell, G. D. \& White, D. A. (1982). The mechanism of cyclic monoterpene inhibition of hepatic 3-hydroxy-3-methylglutaryl coenzyme A reductase in vivo in the rat. Journal of Biological Chemistry 257, 2294-2299.

Clejan, L. A. \& Cederbaum, A. I. (1991). Role of iron, hydrogen peroxide and reactive oxygen species in microsomal oxidation of glycerol to formaldehyde. Archives of Biochemistry and Biophysics 285, 83-89.

Cole, C. B., Fuller, R., Mallett, A. K. \& Rowland, I. R. (1985). The influence of the host on expression of intestinal microbial enzyme activities involved in metabolism of foreign compounds. Journal of Applied Bacteriology 59, 549-553.

Comstock, G. W., Helzlsouer, K. J. \& Bush, T. L. (1991). Prediagnostic serum levels of carotenoids and vitamin $\mathrm{E}$ as related to subsequent cancer in Washington County, Maryland. American Journal of Clinical Nutrition $\mathbf{5 3}$, 260S-264S. 
Correa, P. (1981). Epidemiological correlations between diet and cancer frequency. Cancer Research 41, $3685-3690$.

Crabtree, H. G. (1947). Anti-carcinogenesis. British Medical Bulletin 4, 345-348.

Crowell, P. L., Chang, R. R., Ren, Z., Elson, C. E. \& Gould, M. N. (1991). Selective inhibition of isoprenylation of 21-26 kDa proteins by the anticarcinogen $d$-limonene and its metabolites. Journal of Biological Chemistry 266, 17679-17685.

Dai, Y., Rashbastep, J. \& Cederbaum, A. I. (1993). Stable expression of human cytochrome-P4502E1 in HepG2 cells. Characterization of catalytic activities and production of reactive oxygen intermediates. Biochemistry 32 , 6928-6937.

Daniel, V. (1993). Glutathione S-transferases. Gene structure and regulation of expression. CRC Critical Reviews in Biochemistry and Molecular Biology 28, 173-207.

Dannenberg, A. J. \& Yang, E. K. (1992). Effect of dietary lipids on levels of UDP-glucuronosyltransferase in liver. Biochemical Pharmacology 44, 335-340.

Dawson, M. I., Chao, W.-R. \& Helmes, C. T. (1987). Inhibition by retinoids of anthralin-induced mouse epidermal ornithine decarboxylase activity and anthralin-promoted skin tumor formation. Cancer Research 47, 6210-6215.

Dawson, M. I. \& Okamura, W. H. (1990). Chemistry and Biology of Synthetic Retinoids. Boca Raton, FL: CRC Press.

Deisseroth, A. \& Dounce, A. L. (1970). Catalase: physical and chemical properties, mechanism of catalysis, and physiological role. Physiological Reviews 50, 319-375.

De Long, M. J., Prochaska, H. J. \& Talalay, P. (1986). Induction of NAD(P)H: quinone reductase in murine hepatoma cells by phenolic antioxidants, azo dyes, and other chemoprotectors: a model system for the study of anticarcinogens. Proceedings of the National Academy of Sciences, USA 83, 787-791.

Derbel, M., Igarashi, T. \& Satoh, T. (1993). Differential induction of glutathione S-transferase subunits by phenobarbital, 3-methylcholanthrene and ethoxyquin in rat liver and kidney. Biochimica et Biophysica Acta 1158, 175-180.

Dietrich, D. R., \& Swenberg, J. A. (1991). The presence of $\alpha 2$ u-globulin is necessary for d-limonene promotion of male rat kidney tumors. Cancer Research 51, 3512-3521.

Diplock, A. T. (1991). Antioxidant nutrients and disease prevention: an overview. American Journal of Clinical Nutrition 53, 189S-193S.

Doll, R. \& Peto, R. (1981). The causes of cancer : quantitative estimates of avoidable risks of cancer in the United States today. Journal of the National Cancer Institute 66, 1191-1308.

Donnelly, J. K. \& Robinson, D. S. (1991). Superoxide dismutase. In Oxidative Enzymes in Foods, pp. 49-91 [D. S. Robinson and N. A. M. Eskin, editors]. London: Elsevier Applied Science.

Dunnick, J. K., Prejean, J. D., Haseman, J., Thompson, R. B., Giles, H. D. \& McConnell, E. E. (1982). Carcinogenesis bioassay of allyl isothiocyanate. Fundamental and Applied Toxicology 2, 114-120.

Dutton, G. J. (1980). Glucuronidation of Drugs and Other Compounds. Boca Raton, FL: CRC Press.

Earnest, D. L., Hixson, L. J., Finley, P. R., Blackwell, G. G., Einspahr, J., Emerson, S. S. \& Alberts, D. S. (1992). Arachidonic acid cascade inhibitors in chemoprevention of human colon cancer: preliminary studies. In $C a n c e r$ Chemoprevention, pp. 165-180 [L. Wattenberg, M. Lipkin, C. W. Boone \& G. J. Kelloff, editors]. Boca Raton, FL: CRC Press.

Edwards, Y. H., Potter, J. \& Hopkinson, D. A. (1980). Human FAD-dependent NAD(P)H diaphorase. Biochemical Journal 187, 429-436.

Elegbede, J. A., Elson, C. E., Tanner, M. A., Qureshi, A. \& Gould, M. N. (1986). Regression of rat primary mammary tumors following dietary $d$-limonene. Journal of the National Cancer Institute 76, 323-325.

Enomoto, T. \& Yamasaki, H. (1985). Rapid inhibition of intercellular communication between BALB/c 3T3 cells by diacylglycerol, a possible endogenous functional analog of phorbol esters. Cancer Research 45, 3706-3710.

Fenwick, G. R., Heaney, R. K. \& Mawson, R. (1989). Glucosinolates. In Toxicants of Plant Origin, vol. 2, Glycosides, pp. 1-41 [P. R. Cheeke, editor]. Boca Raton, FL: CRC Press.

Fiala, E. S., Bobotas, G., Kulakis, C., Wattenberg, L. W. \& Weisburger J. H. (1977). Effects of disulfiram and related compounds on the metabolism in vivo of the colon carcinogen, 1,2-dimethylhydrazine. Biochemical Pharmacology 26, $1763-1768$.

Forrester, L. M., Henderson, C. J., Glancey, M. J., Back, D. J., Park, B. K., Ball, S. E., Kitteringham, N. R., McLaren, A. W., Miles, J. S., Skett, P. \& Wolf, C. R. (1992). Relative expression of cytochrome P450 isoenzymes in human liver and association with the metabolism of drugs and xenobiotics. Biochemical Journal 281, 359-368.

Franklin, M. R. (1991). Drug metabolizing enzyme induction by simple diaryl pyridines; 2-substituted isomers selectively increase only conjugation enzyme activities, 4-substituted isomers also induce cytochrome P450. Toxicology and Applied Pharmacology 111, 24-32.

Frenkel, K., Chrzan, K., Ryan, C. A., Wiesner, R. \& Troll, W. (1987). Chymotrypsin-specific protease inhibitors decrease hydrogen peroxide formation by activated human polymorphonuclear leukocytes. Carcinogenesis $\mathbf{8}$, 1207-1212.

Friling, R. S., Bergelson, S. \& Daniel, V. (1992). Two adjacent AP-1 like binding sites form the electrophile responsive element of the murine glutathione S-transferase Ya subunit gene. Proceedings of the National Academy of Sciences, USA 89, 668-672. 
Fuhr, U., Klittich, K. \& Staib, A. H. (1993). Inhibitory effect of grapefruit juice and its bitter principal, naringenin, on CYP1A2 dependent metabolism of caffeine in man. British Journal of Clinical Pharmacology 35, 431-436.

Fujii-Kuriyama, Y., Imataka, H., Sogawa, K., Yasumoto, K.-I. \& Kikuchi, Y. (1992). Regulation of CYPIAl expression. FASEB Journal 6, 706-710.

Fujiki, H., Horiuchi, T., Yamashita, K., Hakii, H., Suganuma, M., Nishino, H., Iwashima, A., Hirata, Y. \& Sugimura, T. (1986). Inhibition of tumor promotion by flavonoids. Progress in Clinical and Biological Research 213, 429-440.

Fujiki, H., Suganuma, M., Yoshizawa, S., Yatsunami, J., Nishikawa, S., Furuya, H., Okabe, S., NishiwakiMatsushima, R., Matsunaga, S., Muto, Y., Okuda, T. \& Sugimura, T. (1992). Sarcophytol A and (-)epigallocatechin gallate (EGCG), nontoxic inhibitors of cancer development. In Cancer Chemoprevention, pp. 393-405 [L. Wattenberg, M. Lipkin, C. W. Boone \& G. J. Kelloff, editors]. Boca Raton, FL: CRC Press.

Gadelle, D., Raibaud, P. \& Sacquet, E. (1985). $\beta$-Glucuronidase activities of intestinal bacteria determined both in vitro and in vivo in gnotobiotic rats. Applied and Environmental Microbiology 49, 682-685.

Gandhi, R. K. \& Khanduja, K. L. (1992). Action of caffeine in altering the carcinogen-activating and carcinogendetoxifying enzymes in mice. Journal of Clinical Biochemistry and Nutrition 12, 19-26.

Garte, S. J., Currie, D. D. \& Troll, W. (1987). Inhibition of H-ras oncogene transformation of NIH 3T3 cells by protease inhibitors. Cancer Research 47, 3159-3162.

Godar, D. E., Thomas, D. P., Miller, S. A. \& Lee, W. (1993). Long-wavelength UVA radiation induces oxidative stress, cytoskeletal damage and hemolysis. Photochemistry and Photobiology 57, 1018-1026.

Gonzalez, F. J., Liu, S. Y. \& Yano, M. (1993). Regulation of cytochrome-P450 genes - molecular mechanisms. Pharmacogenetics 3, 51-57.

Goodlad, R. A., Madgwick, A. J., Moffatt, M. R., Levin, S., Allen, J. L. \& Wright, N. A. (1989). Prostaglandins and the gastric epithelium: effects of misoprostol on gastric epithelial cell proliferation in the dog. Gut $\mathbf{3 0}$, 316-321.

Goodwin, J. S. (1984). Immunologic effects of nonsteroidal anti-inflammatory drugs. American Journal of Medicine 77 (4B), 7-15.

Griepentrog, F. (1973). [Pathological-anatomical results on the effect of coumarin in animal experiments.] Toxicology 1, 93-102

Groden, J., Nakamura, Y. \& German, J. (1990). Molecular evidence that homologous recombination occurs in proliferating human somatic cells. Proceedings of the National Academy of Sciences, USA 87, 4315-4319.

Grubbs, C. J., Eto, I., Juliana, M. M. \& Whitaker, L. M. (1991). Effect of canthaxanthin on chemically induced mammary carcinogenesis. Oncology 48, 239-245.

Guengerich, F. P. (1992a). Metabolic activation of carcinogens. Pharmacology \& Therapeutics 54, 17-61.

Guengerich, F. P. (1992b). Human cytochrome-P-450 enzymes. Life Sciences 50, 1471-1478.

Guo, Z., Smith, T. J., Wang, E., Eklind, K. I., Chung, F. L. \& Yang, C. S. (1993). Structure-activity relationships of arylalkyl isothiocyanates for the inhibition of 4-(methylnitrosamino)-1-(3-pyridyl)-1-butanone metabolism and the modulation of xenobiotic-metabolizing enzymes in rats and mice. Carcinogenesis 14, $1167-1173$.

Halliwell, B. (1990). How to characterize a biological antioxidant. Free Radical Research Communications 9, 1-32.

Hial, V., De Mello, M. C. F., Horakova, Z. \& Beaven, M. A. (1977). Antiproliferative activity of antiinflammatory drugs in two mammalian cell culture lines. Journal of Pharmacology and Experimental Therapeutics 202, 446-454.

Hirose, K., Longo, D. L., Oppenheim, J. J. \& Matsushima, K. (1993). Overexpression of mitochondrial manganese superoxide dismutase promotes the survival of tumor cells exposed to interleukin-1, tumor necrosis factor, selected anticancer drugs, and ionizing radiation. FASEB Journal 7, 361-368.

Hochstein, P., Atallah, A. S. \& Ernster, L. (1988). DT diaphorase and the toxicity of quinones: status and perspectives. In Cellular Antioxidant Defense Mechanisms, vol. 2, pp. 123-131 [C. K. Chow, editor]. Boca Raton, FL: CRC Press.

Horie, T., Awazu, S., Itakura, Y. \& Fuwa, T. (1992). Identified diallyl polysulfides from an aged garlic extract which protects the membranes from lipid peroxidation. Planta Medica 58, 468-469.

Hossain, M. Z., Wilkens, L. R., Mehta, P. P., Loewenstein, W. \& Bertram, J. S. (1989). Enhancement of gap junctional communication by retinoids correlates with their ability to inhibit neoplastic transformation. Carcinogenesis 10, 1743-1748.

Howie, A. F., Forrester, L. M., Glancey, M. J., Schlager, J. J., Powis, G., Beckett, G. J., Hayes, J. D. \& Wolf, C. R. (1990). Glutathione S-transferase and glutathione peroxidase expression in normal and tumour human tissues. Carcinogenesis 11, 451-8.

Hsu, C.-J., Kirkman, B. R. \& Fishman, J. (1991). Differential expression of oncogenes c-fos, c-myc and neu/Her 2 induced by estradiol and 16 -hydroxyestrone in human cancer cell line. Seventh Annual Meeting of the Endocrine Society Abstract 586.

Huang, D. S., Odeleye, O. E. \& Watson, R. R. (1992). Inhibitory effects of canthaxanthin on in vitro growth of murine tumor cells. Cancer Letters 65, 209-213.

Huang, M.-T., Lysz, T., Ferraro, T., Abidi, T. F., Laskin, J. D. \& Conney, A. H. (1991). Inhibitory effects of curcumin on in vitro lipoxygenase and cyclooxygenase activities in mouse epidermis. Cancer Research 51 , 813-819. 
Huang, M.-T., Smart, R. C., Wong, C.-Q. \& Conney, A. H. (1988). Inhibitory effect of curcumin, chlorogenic acid, caffeic acid, and ferulic acid on tumor promotion in mouse skin by 12-O-tetradecanoylphorbol-13-acetate. Cancer Research 48, 5941-5946.

Imanishi, H., Sasaki, Y. F., Matsumoto, K., Watanabe, M., Ohta, T., Shirasu, Y. \& Tutikawa, K. (1990). Suppression of 6-TG-resistant mutations in V79 cells and recessive spot formations in mice by vanillin. Mutation Research 243, 151-158.

Imanishi, H., Sasaki, Y. F., Ohta, T., Watanabe, M., Kato, T. \& Shirasu, Y. (1991). Tea tannin components modify the induction of sister-chromatid exchanges and chromosome aberrations in mutagen-treated cultured mammalian cells and mice. Mutation Research 259, 79-87.

Inouye, T., Sasaki, Y. F., Imanishi, H., Watanabe, M., Ohta, T. \& Shirasu, Y. (1988). Suppression of mitomycin $\mathrm{C}$-induced micronuclei in mouse bone marrow cells by post-treatment with vanillin. Mutation Research 202 , 93-95.

Ishidate, M., Harnois, M. C. \& Sofuni, T. (1988). A comparative analysis of data on the clastogenicity of 951 chemical substances tested in mammalian cell cultures. Mutation Research 195, 151-213.

Ishikawa, T. (1992). The ATP-dependent glutathione S-conjugate export pump. Trends in Biochemical Sciences 17, 463-468.

Iwata, N., Minegishi, K., Suzuki, K., Ohno, Y., Igarashi, T., Satoh, T. \& Takahashi, A. (1993). An unusual profile of musk xylene-induced drug-metabolizing enzymes in rat liver. Biochemical Pharmacology 45, 1659-1665.

Jansson, T. \& Zech, L. (1987). Effects of vanillin on sister-chromatid exchanges and chromosome aberrations in human lymphocytes. Mutation Research 190, 221-224.

Jellinck, P. H., Forkert, P. G., Riddick, D. S., Okey, A. B., Michnovicz, J. J. \& Bradlow, H. L. (1993). Ah receptor binding properties of indole carbinols and induction of hepatic estradiol hydroxylation. Biochemical Pharmacology 45, 1129-1136.

Jyonouchi, H., Hill, R. J., Tomita, Y. \& Good, R. A. (1991). Studies of immunomodulating actions of carotenoids. I. Effects of $\beta$-carotene and astaxanthin on murine lymphocyte functions and cell surface marker expression in in vitro culture system. Nutrition and Cancer 16, 93-105.

Jyonouchi, H., Zhang, L. \& Tomita, Y. (1993). Studies of immunomodulating actions of carotenoids. II. Astaxanthin enhances in vitro antibody production to $\mathrm{T}$-dependent antigens without facilitating polyclonal B-cell activation. Nutrition and Cancer 19, 269-280.

Kasamaki, A., Takahashi, H., Tsumura, N., Niwa, J., Fujita, T. \& Urasawa, S. (1982). Genotoxicity of flavoring agents. Mutation Research 105, 387-392.

Kasamaki, A., Yasuhara, T. \& Urasawa, S. (1987). Neoplastic transformation of Chinese hamster cells in vitro after treatment with flavoring agents. Journal of Toxicological Sciences 12, 383-396.

Kato, K., Cox, A. D., Hisaka, M. M., Graham, S. M., Buss, J. E. \& Der, C. J. (1992). Isoprenoid addition to Ras protein is the critical modification for its membrane association and transforming activity. Proceedings of the National Academy of Sciences, USA 89, 6403-6407.

Kato, R., Nakadate, T., Yamamoto, S. \& Sugimura, T. (1983). Inhibition of 12-O-tetradecanoylphorbol-13acetate-induced tumor promotion and ornithine decarboxylase activity by quercetin: possible involvement of lipoxygenase inhibition. Carcinogenesis 4, 1301-1305.

Kennedy, A. R. \& Little, J. B. (1981). Effects of protease inhibitors on radiation transformation in vitro. Cancer Research 41, 2103-2108.

Kilgore, K. S. \& Lucchesi, B. R. (1993). Reperfusion injury after myocardial infarction: the role of free radicals and the inflammatory response. Clinical Biochemistry 26, 359-370.

Klone, A., Hussnatter, R. \& Sies, H. (1992). Cloning, sequencing and characterization of the human alphaglutathione S-transferase gene corresponding to the cDNA clone pGTH2. Biochemical Journal 285, $925-928$.

Kore, A. M., Jeffery, E. H. \& Wallig, M. A. (1993). Effects of 1-isothiocyanato-3-(methylsulfinyl)-propane on xenobiotic metabolizing enzymes in rats. Food and Chemical Toxicology 31, 723-729.

Korpássy, B. \& Mosonyi, M. (1950). The carcinogenic activity of tannic acid. Liver tumours induced in rats by prolonged subcutaneous administration of tannic acid solutions. British Journal of Cancer 4, 411-420.

Krinsky, N. I. (1993). Actions of carotenoids in biological systems. Annual Review of Nutrition 13, 561-587.

Ladenstein, R. (1984). Molecular enzymology of seleno-glutathione peroxidase. Peptide and Protein Reviews 4, 173-214.

Landers, J. P. \& Bunce, N. J. (1991). The Ah receptor and the mechanism of dioxin toxicity. Biochemical Journal 276, 273-287.

Larocca, L. M., Teofili, L., Leone, G., Sica, S., Pierelli, L., Menichella, G., Scambia, G., Benedetti Panici, P., Ricci, R., Piantelli, M. \& Ranelletti, F. O. (1991). Antiproliferative activity of quercetin on normal bone marrow and leukaemic progenitors. British Journal of Haematology 79, 562-566.

Lee, H. P., Gourley, L., Duffy, S. W., Estève, J., Lee, J. \& Day, N. E. (1991). Dietary effects on breast-cancer risk in Singapore. Lancet 337, 1197-1200.

Lee, R. B. (1967). What Hunters Do for a Living: A Comparative Study in Man the Hunter, p. 41 [R. B. Lee and D. Vore, editors]. Chicago: Aldine.

Levine, L., Hinkle, P. M., Voelkel, E. F. \& Tashjian, A. H. (1972). Prostaglandin production by mouse fibrosarcoma cells in culture: inhibition by indomethacin and aspirin. Biochemical and Biophysical Research Communications 47, 888-896.

Li, Y. \& Jaiswal, A. K. (1992). Regulation of human NAD(P)H: quinone oxidoreductase gene - role of AP1 
binding site contained within human antioxidant response element. Journal of Biological Chemistry 267, $15097-15104$.

Lind, C., Hochstein, P. \& Ernster, L. (1982). DT-diaphorase as a quinone reductase: a cellular control device against semiquinone and superoxide radical formation. Archives of Biochemistry and Biophysics 216, 178-185.

Liu, J. \& Mori, A. (1993). Antioxidant and pro-oxidant activities of $p$-hydroxybenzyl alcohol and vanillin: effects on free radicals, brain peroxidation and degradation of benzoate, deoxyribose, amino acids and DNA. Neuropharmacology 32, 659-669.

Lotan, R. (1980). Effects of vitamin A and its analogs (retinoids) on normal and neoplastic cells. Biochimica et Biophysica Acta 605, 33-91.

Lotan, R. (1992a). Evaluation of the results of clinical trials with retinoids in relation to their basic mechanism of action. In Cancer Chemoprevention, pp. 71-82 [L. Wattenberg, M. Lipkin, C. W. Boone \& G. J. Kelloff, editors]. Boca Raton, FL: CRC Press.

Lotan, R. (1992b). Cell invasion as a target for chemoprevention. In Cellular and Molecular Targets for Chemoprevention, pp. 339-350 [V. E. Steele, G. D. Stoner, C. W. Boone \& G. J. Kelloff, editors]. Boca Raton, FL: CRC Press.

Lucas, D., Menez, J. F., Berthou, F., Cauvin, J. M. \& Deitrich, R. A. (1992). Differences in hepatic microsomal cytochrome P-450 isoenzyme induction by pyrazole, chronic ethanol, 3-methylcholanthrene, and phenobarbital in high alcohol sensitivity (HAS) and low alcohol sensitivity (LAS) rats. Alcoholism-Clinical and Experimental Research 16, 916-921.

Luk, G. D. (1992). Clinical and biologic studies of DFMO in the colon. In Cancer Chemoprevention, pp. 515-530 [L. Wattenberg, M. Lipkin, C. W, Boone \& G. J. Kelloff, editors]. Boca Raton, FL: CRC Press.

McCann, P. P., Bitonti, A. J. \& Pegg, A. E. (1992). Inhibition of polyamine metabolism and the consequent effects on cell proliferation. In Cancer Chemoprevention, pp. 531-539 [L. Wattenberg, M. Lipkin, C. W. Boone \& G. J. Kelloff, editors]. Boca Raton, FL: CRC Press.

McManus, M. E. \& McKinnon, R. A. (1991). Measurement of cytochrome P450 activation of xenobiotics using the Ames Salmonella test. Methods in Enzymology 206, 501-509.

Maeda, S. \& Nakagawa, M. (1977). General chemical and physical analyses on various kinds of green tea. Chagyo Kenkyu Hokoku 45, 85-92.

Maiorino, M., Zamburlini, A., Roveri, A. \& Ursini, F. (1993). Prooxidant role of vitamin-E in copper induced lipid peroxidation. FEBS Letters 330, 174-176.

Mallett, A. K., Bearne, C. A., Lake, B. G. \& Rowland, I. R. (1989). Modified mutagen activation in hepatic fractions from rats fed dietary rutin. Interaction between gut flora and host metabolism. Food and Chemical Toxicology 27, 607-611.

Mallett, A. K. \& Rowland, I. R. (1990). Bacterial enzymes: their role in the formation of mutagens and carcinogens in the intestine. Digestive Diseases 8, 71-79.

Mamont, P. S., Böhlen, P., McCann, P. P., Bey, P., Schuber, F. \& Tardif, C. (1976). $\alpha$-Methyl ornithine, a potent competitive inhibitor of ornithine decarboxylase, blocks proliferation of rat hepatoma cells in culture. Proceedings of the National Academy of Sciences, USA 73, 1626-1630.

Mannervik, B. (1985). The isoenzymes of glutathione transferase. Advances in Enzymology 57, $357-417$.

Mannervik, B., Alin, P., Guthenberg, C., Jensson, H. \& Warholm, M. (1985). Glutathione transferases and the detoxification of products of oxidative metabolism. In Proceedings of the 6th International Symposium on Microsomes and Drug Oxidations, pp. 221-228 [A. R. Boobis, J. Caldwell, F. De Mattheis \& C. R. Elcombe, editors]. London: Taylor \& Francis.

Manervik, B. \& Danielson, U. H. (1988). Glutathione S-transferases - structure and catalytic activity. $C R C$ Critical Reviews in Biochemistry 23, 283-337.

Markaverich, B. M., Roberts, R. R., Alejandro, M. A., Johnson, G. A., Middleditch, B. S. \& Clark, J. H. (1988). Bioflavonoid interaction with rat uterine type II binding sites and cell growth inhibition. Journal of Steroid Biochemistry 30, 71-78.

Maruta, A., Enaka, K. \& Umeda, M. (1979). Mutagenicity of quercetin and kaempferol on cultured mammalian cells. GANN 70, 273-276.

Mathews-Roth, M. M. (1982). Antitumor activity of $\beta$-carotene, canthaxanthin and phytoene. Oncology 39, 33-37.

Meister, A. (1991). Glutathione deficiency produced by inhibition of its synthesis, and its reversal; applications in research and therapy. Pharmacology and Therapeutics 51, 155-194.

Michnovicz, J. J. \& Bradlow, H. L. (1990). Induction of estradiol metabolism by dietary indole-3-carbinol in humans. Journal of the National Cancer Institute 82, 947-949.

Michnovicz, J. J. \& Bradlow, H. L. (1991). Altered estrogen metabolism and excretion in humans following consumption of indole-3-carbinol. Nutrition and Cancer 16, 59-66.

Miners, J. O. \& Mackenzie, P. I. (1991). Drug glucuronidation in humans. Pharmacology and Therapeutics 51, 347-369.

Minotti, G., Di Gennaro, M., D’Ugo, D. \& Granone, P. (1991). Possible sources of iron for lipid peroxidation. Free Radical Research Communications 12-13, 99-106.

Moncada, S., Flower, R. J. \& Vane, J. R. (1980). Prostaglandins, prostacyclin, and thromboxane $\mathrm{A}_{2}$. In Goodman and Gilman's The Pharmacological Basis of Therapeutics, 6th edn, pp. 668-681 [A. G. Gilman, L. S. Goodman \& A. Gilman, editors]. New York: MacMillan. 
Moon, R. C., Rao, K. V. N., Detrisac, C. J. \& Kelloff, G. J. (1992). Retinoid chemoprevention of lung cancer. In Cancer Chemoprevention, pp. 83-93 [L. Wattenberg, M. Lipkin, C. W. Boone \& G. J. Kelloff, editors]. Boca Raton, FL: CRC Press.

Morel, I., Lescoat, G., Cogrel, P., Sergent, O., Pasdeloup, N., Brissot, P., Cillard, P. \& Cillard, J. (1993). Antioxidant and iron-chelating activities of the flavonoids catechin, quercetin and diosmetin on iron-loaded rat hepatocyte cultures. Biochemical Pharmacology 45, 13-19.

Mori, A., Nishino, C., Enoki, N. \& Tawata, S. (1988). Cytotoxicity of plant flavonoids against HeLa cells. Phytochemistry 27, 1017-1020.

Morse, M. A., Eklind, K. I., Amin, S. G., Hecht, S. S. \& Chung, F. L. (1989). Effects of alkyl chain length on the inhibition of NNK-induced lung neoplasia in $\mathrm{A} / \mathrm{J}$ mice by arylalkyl isothiocyanates. Carcinogenesis 10 , $1757-1759$.

Morse, M. A. \& Stoner, G. D. (1993). Cancer chemoprevention: principles and prospects. Carcinogenesis 14, $1737-1746$.

Mukai, K., Sawada, K., Kohno, Y. \& Terao, J. (1993). Kinetic study of the prooxidant effect of tocopherol. Hydrogen abstraction from lipid hydroperoxides by tocopheroxyls in solution. Lipids 28, 747-752.

Murphy, S. P., Subar A. F. \& Block G. (1990). Vitamin E intakes and sources in the United States. American Journal of Clinical Nutrition 52, 361-367.

Murray, A. W., Fournier, A. \& Hardy, S. J. (1978). Proteolytic activation of protein kinase C: a physiological reaction? Trends in Biochemical Science 12, 53-54.

Musk, S. R. R. \& Johnson, I. T. (1993a). Allyl isothiocyanate is selectively toxic to transformed cells of the human colorectal tumour line HT29. Carcinogenesis 14, 2079-2083.

Musk, S. R. R. \& Johnson, I. T. (1993b). In vitro genetic toxicology testing of naturally occurring isothiocyanates. In Food and Cancer Prevention: Chemical and Biological Aspects, pp. $58-61$ [K. W. Waldron, I. T. Johnson \& G. R. Fenwick, editors]. Cambridge: Royal Society of Chemistry.

Nagasawa, H. \& Konishi, R. (1988). Stimulation by caffeine of spontaneous mammary tumorigenesis in mice. European Journal of Cancer and Clinical Oncology 24, 803-805.

Nakadate, T., Yamamoto, S., Aizu, E. \& Kato, R. (1984). Effects of flavonoids and antioxidants on 12-Otetradecanoylphorbol-13-acetate-caused epidermal ornithine decarboxylase induction and tumor promotion in relation to lipoxygenase inhibition by these compounds. GANN 75, 214-222.

Nanno, M., Morotomi, M., Takayama, H., Kuroshima, T., Tanaka, R. \& Mutai, M. (1986). Mutagenic activation of biliary metabolites of benzo(a)pyrene by $\beta$-glucuronidase-positive bacteria in human faeces. Journal of Medical Microbiology 22, 351-355.

Nelson, D. R., Kamataki, T., Waxman, D. J., Guengerich, F. P., Estabrook, R. W., Feyereisen, R., Gonzalez, F. J., Coon, M. J., Gunsalus, I. C., Gotoh, O., Okuda, K. \& Nebert, D. W. (1993). The P450 superfamily - update on new sequences, gene mapping, accession numbers, early trival names of enzymes, and nomenclature. $D N A$ and Cell Biology 12, 1-51.

Nguyen, T. \& Pickett, C. B. (1992). Regulation of rat glutathione $S$-transferase Ya subunit gene expression DNA-protein interaction at the antioxidant responsive element. Journal of Biological Chemistry 267, $13535-13539$.

Nijhoff, W. A., Groen, G. M. \& Peters, W. H. M. (1993). Induction of rat hepatic and intestinal glutathione Stransferases and glutathione by dietary naturally occurring anticarcinogens. International Journal of Oncology 3, 1131-1139.

Nishikawa, A., Furukawa, F., Imazawa, T., Yoshimura, H., Mitsumori, K. \& Takahashi, M. (1992). Effects of caffeine, nicotine, ethanol and sodium selenite on pancreatic carcinogenesis in hamsters after initiation with $N$ nitrosobis(2-oxopropyl)amine. Carcinogenesis 13, 1379-1382.

Nishino, H. (1992). Antitumor-promoting activity of glycyrrhetinic acid and its related compounds. In Cancer Chemoprevention, pp. 457-467 [L. Wattenberg, M. Lipkin, C. W. Boone \& G. J. Kelloff, editors]. Boca Raton, FL: CRC Press.

Nomura, A., Henderson, B. E. \& Lee, J. (1978). Breast cancer and diet among the Japanese in Hawai. American Journal of Clinical Nutrition 31, 2020-2025.

O'Brian, C. A., Ward, N. E. \& Vogel, V. G. (1990). Inhibition of protein kinase C by the 12-O-tetradecanoylphorbol-13-acetate antagonist glycyrrhetic acid. Cancer Letters 49, 9-12.

Oguni, I., Nasu, K., Kanaya, S., Ota, Y., Yamamoto, S. \& Nomura, T. (1989). Epidemiological and experimental studies on the antitumor activity by green tea extracts. Japanese Journal of Nutrition 47, 43-48.

Ohmori, S., Misaizu, T., Nakamura, T., Takano, N., Kitagawa, H. \& Kitada, M. (1993). Differential role in lipid peroxidation between rat P450 1A1 and P450 1A2. Biochemical Pharmacology 46, 55-60.

Ohta, T., Watanabe, K., Moriya, M., Shirasu, Y. \& Kada, T. (1983a). Anti-mutagenic effects of coumarin and umbelliferone on mutagenesis induced by 4-nitroquinoline 1-oxide or UV irradiation in E. coli. Mutation Research 117, 135-138.

Ohta, T., Watanabe, K., Moriya, M., Shirasu, Y. \& Kada, T. (1983b). Analysis of the antimutagenic effect of cinnamaldehyde on chemically induced mutagenesis in Escherichia coli. Molecular and General Genetics 192, $309-315$.

Ohta, T., Watanabe, M., Shirasu, Y. \& Inoue, T. (1988). Post-replication repair and recombination in $u v r A$ umuC strains of Escherichia coli are enhanced by vanillin, an antimutagenic compound. Mutation Research 201, $107-112$. 
Ohta, T., Watanabe, M., Watanabe, K., Shirasu, Y. \& Kada, T. (1986). Inhibitory effects of flavourings on mutagenesis induced by chemicals in bacteria. Food and Chemical Toxicology 24, 51-54.

Okuzumi, J., Nishino, H., Murakoshi, M., Iwashima, A., Tanaka, Y., Yamane, T., Fujita, Y. \& Takahashi, T. (1990). Inhibitory effects of fucoxanthin, a natural carotenoid, on N-myc expression and cell cycle progression in human malignant tumor cells. Cancer Letters 55, 75-81.

Okuzumi, J., Takahashi, T., Yamane, T., Kitao, Y., Inagake, M., Ohya, K., Nishino, H. \& Tanaka, Y. (1993). Inhibitory effects of fucoxanthin, a natural carotenoid, on $N$-ethyl- $N^{\prime}$-nitro- $N$-nitrosoguanidine-induced mouse duodenal carcinogenesis. Cancer Letters 68, 159-168.

Pacifici, R. E. \& Davies, K. J. A. (1990). Protein degradation as an index of oxidative stress. Methods in Enzymology 186, 485-502.

Packer, L. (1991). Protective role of vitamin E in biological systems. American Journal of Clinical Nutrition 53, 1050S-1055S.

Packer, L. (1992). New horizons in vitamin E research - the vitamin E cycle, biochemistry, and clinical applications, In Lipid-soluble Antioxidants: Biochemistry and Clinical Applications, pp. 1-15 [A. S. H. Ong and L. Packer, editors]. Basel: Birkhauser Verlag.

Pegg, A.E. (1988). Polyamine metabolism and its importance in neoplastic growth and as a target for chemotherapy. Cancer Research 48, 759-774.

Pence, B. C., Buddingh, F. \& Yang, S. P. (1986). Multiple dietary factors in the enhancement of dimethylhydrazine carcinogenesis: main effect of indole-3-carbinol. Journal of the National Cancer Institute 77, 269-276.

Powell, S. R. \& Tortolani, A. J. (1992). Recent advances in the role of reactive oxygen intermediates in ischemic injury. 1. Evidence demonstrating presence of reactive oxygen intermediates. 2. Role of metals in site-specific formation of radicals. Journal of Surgical Research 53, 417-429.

Pratt, D. E. (1992). Natural antioxidants from plant material. In Phenolic Compounds in Food and their Effect on Health, vol. 2, pp. 54-71. [M.-T. Huang, C.-T. Ho \& C. Y. Lee, editors]. Washington DC: American Chemical Society.

Preston-Martin, S., Pike, M. C., Ross, R. K., Jones, P. A. \& Henderson, B. E. (1990). Increased cell division as a cause of human cancer. Cancer Research 50, 7415-7421.

Prochaska, H. J., De Long, M. J. \& Talalay, P. (1985). On the mechanisms of induction of cancer-protective enzymes: a unifying proposal. Proceedings of the National Academy of Sciences, USA 82, 8232-8236.

Prochaska, H. J. \& Santamaria, A. B. (1988). Direct measurement of NAD(P)H:quinone reductase from cells cultured in microtiter wells: a screening assay for anticarcinogenic enzyme inducers. Analytical Biochemistry 169, 328-336.

Pung, A., Rundhaug, J. E., Yoshizawa, C. N. \& Bertram, J. S. (1988). $\beta$-Carotene and canthaxanthin inhibit chemically- and physically-induced neoplastic transformation in 10T1/2 cells. Carcinogenesis 9, 1533-1539.

Rao, C. V., Simi, B. \& Reddy, B. S. (1993). Inhibition by dietary curcumin of azoxymethane-induced ornithine decarboxylase, tyrosine protein kinase, arachidonic acid metabolism and aberrant crypt foci formation in the rat colon. Carcinogenesis 14, 2219.2225.

Raveendran, M., Thanislass, J., Maheswari, G. U. \& Devaraj, H. (1993). Induction of prooxidant state by the food flavor cinnamaldehyde in rat liver. Journal of Nutritional Biochemistry 4, 181-183.

Reddy, B. S., Weisburger, J. H., Narisawa, T. \& Wynder, E. L. (1974). Colon carcinogenesis in germ-free rats treated with 1,2-dimethylhydrazine and $N$-methyl- $N^{\prime}$-nitro- $N$-nitrosoguanidine. Cancer Research 34, 23682372.

Reif, D. W. (1992). Ferritin as a source of iron for oxidative damage. Free Radical Biology and Medicine 12, $417-427$.

Remacle, J., Lambert, D., Raes, M., Pigeolet, E., Michiels, C. \& Toussaint, O. (1992). Importance of various antioxidant enzymes for cell stability - confrontation between theoretical and experimental data. Biochemical Journal 286, 41-46.

Riley, R. J. \& Workman, P. (1992). DT-diaphorase and cancer chemotherapy. Biochemical Pharmacology 43, $1657-1669$.

Rousseau, E. J., Davison, A. J. \& Dunn, B. (1992). Protection by $\beta$-carotene and related compounds against oxygen-mediated cytotoxicity and genotoxicity - implications for carcinogenesis and anticarcinogenesis. Free Radical Biology and Medicine 13, 407-433.

Rowland, I. R., Mallett, A. K. \& Wise, A. (1985). The effect of diet on the mammalian gut flora and its metabolic activities. CRC Critical Reviews in Toxicology 16, 31-103.

Rozen, F., Nguyen, T. \& Pickett, C. B. (1992). Isolation and characterization of a human glutathione Stransferase $\mathrm{Hal}$ subunit gene. Archives of Biochemistry and Biophysics 292, 589-593.

Ruch, R. J., Cheng, S.-J. \& Klaunig, J. E. (1989). Prevention of cytotoxicity and inhibition of intercellular communication by antioxidant catechins isolated from Chinese green tea. Carcinogenesis 10, 1003-1008.

Rueff, J., Laires, A., Gaspar, J., Borba, H. \& Rodrigues, A. (1992). Oxygen species and the genotoxicity of quercetin. Mutation Research 265, 75-81.

Rushmore, T. H., Morton, M. R. \& Pickett, C. B. (1991). The antioxidant responsive element. Activation by oxidative stress and identification of the DNA consensus sequence required for functional activity. Journal of Biological Chemistry 266, 11632-11639.

Rushmore, T. H. \& Pickett, C. B. (1993). Glutathione S-transferases, structure, regulation, and therapeutic implications. Journal of Biological Chemistry 268, 11475-11478. 
Saatcioglu, F., Perry, D. J., Pasco, D. S. \& Fagan, J. B. (1990). Aryl hydrocarbon (Ah) receptor DNA binding activity. Sequence specificity and $\mathrm{Zn}^{2+}$ requirement. Journal of Biological Chemistry 265, 9251-9258.

Sasaki, Y. F., Imanishi, H., Ohta, T. \& Shirasu, Y. (1987). Effects of vanillin on sister-chromatid exchanges and chromosome aberrations induced by mitomycin $\mathrm{C}$ in cultured Chinese hamster ovary cells. Mutation Research $191,193-200$.

Sasaki, Y. F., Imanishi, H., Watanabe, M., Ohta, T. \& Shirasu, Y. (1990a). Suppressing effect of antimutagenic flavorings on chromosome aberrations induced by UV-light or X-rays in cultured Chinese hamster cells. Mutation Research 229, 1-10.

Sasaki, Y. F., Ohta, T., Imanishi, H., Watanabe, M., Matsumoto, K., Kato, T, \& Shirasu, Y. (1990b). Suppressing effects of vanillin, cinnamaldehyde, and anisaldehyde on chromosome aberrations induced by $\mathrm{X}$-rays in mice. Mutation Research 243, 299-302.

Sato, M., Narisawa, T., Sano, M., Takahashi, T. \& Goto, A. (1983). Growth inhibition of transplantable murine colon adenocarcinoma 38 by indomethacin. Journal of Cancer Research and Clinical Oncology 106, $21-26$.

Schelp, F.-P. \& Pongpaew, P. (1988). Protection against cancer through nutritionally-induced increase of endogenous proteinase inhibitors - a hypothesis. International Journal of Epidemiology 17, 287-292.

Schneider, J., Huh, M. M., Bradlow, H. L. \& Fishman, J. (1984). Antiestrogen action of 2-hydroxyestrone on MCF-7 human breast cancer cells. Journal of Biological Chemistry 259, 4840-4845.

Scholar, E. M., Wolterman, K., Birt, D. F. \& Bresnick, E. (1989). The effect of diets enriched in cabbage and collards on murine pulmonary metastasis. Nutrition and Cancer 12, 121-126.

Schrauzer, G. N. (1992). Mechanistic aspects of anticarcinogenic action. Biological Trace Element Research 33, $51-62$.

Schuckelt, R., Brigelius-Flohe, R., Maiorino, M., Roveri, A., Reumkens, J., Strassburger, W., Ursini, F., Wolf, B. \& Flohe, L. (1991). Phospholipid hydroperoxide glutathione peroxidase is a selenoenzyme distinct from the classical glutathione peroxidase as evident from cDNA and amino acid sequencing. Free Radical Research Communications 14, 343-361.

Scott, B. C., Butler, J., Halliwell, B. \& Aruoma, O. I. (1993). Evaluation of the antioxidant actions of ferulic acid and catechins. Free Radical Research Communications 19, 241-253.

Setchell, K. D. R. \& Aldercreutz, H. (1988). Mammalian lignans and phyto-oestrogens. Recent studies on their formation, metabolism and biological role in health and disease. In Role of the Gut Flora in Toxicity and Cancer, pp. 315-345 [I. R. Rowland, editor]. London: Academic Press.

Shamsuddin, A. M. \& Sakamoto, K. (1992). Antineoplastic action of inositol compounds. In Cancer Chemoprevention, pp. 285-308 [L. Wattenberg, M. Lipkin, C. W. Boone \& G. J. Kelloff, editors]. Boca Raton, FL: CRC Press.

Shamsuddin, A. M. \& Ullah, A. (1989). Inositol hexaphosphate inhibits large intestinal cancer in F344 rats 5 months following induction by azoxymethane. Carcinogenesis 10, 625-626.

Shertzer, H. G. \& Sainsbury, M. (1991). Chemoprotective and hepatic enzyme induction properties of indole and indenoindole antioxidants in rats. Food and Chemical Toxicology 29, 391-400.

Shi, X., Dalal, N. S. \& Jain, A. C. (1991). Antioxidant behaviour of caffeine: efficient scavenging of hydroxyl radicals. Food and Chemical Toxicology 29, $1-6$.

Shimoi, K., Nakamura, Y., Tomita, I, Hara, Y.\& Kada, T. (1986). The pyrogallol related compounds reduce UVinduced mutations in Escherichia coli B/r WP2. Mutation Research 173, 239-244.

Shimoi, K., Nakamura, Y., Tomita, I. \& Kada, T. (1985). Bio-antimutagenic effects of tannic acid on UV and chemically induced mutagenesis in Escherichia coli B/r. Mutation Research 149, 17-23.

Shklar, G. \& Schwartz, J. (1988). Tumor necrosis factor in experimental cancer regression with alphatocopherol, beta-carotene, canthaxanthin and algae extract. European Journal of Cancer and Clinical Oncology 24, 839-850.

Slaga, T. J. (1983). Overview of tumor promotion in animals. Environmental Health Perspectives 50, 3-14.

Smith, T. J., Guo, Z., Li, C., Ning, S. M.,Thomas, P. E. \& Yang, C. S. (1993). Mechanisms of inhibition of 4(methylnitrosamino)-1-(3-pyridyl)-1-butanone bioactivation in mouse by dietary phenethyl isothiocyanate. Cancer Research 53, 3276-3282.

Soudamini, K. K. \& Kuttan, R. (1989). Inhibition of chemical carcinogenesis by curcumin. Journal of Ethnopharmacology 27, 227-233.

Stähelin, H. B., Gey, K. F., Eichholzer, M. \& Lüdin, E. (1991). $\beta$-Carotene and cancer prevention: the Basel study. American Journal of Clinical Nutrition 53, 265S-269S.

Sugie, S., Yoshimi, N., Okumara, A., Tanaka, T. \& Mori, H. (1993). Modifying effects of benzyl isothiocyanate and benzyl thiocyanate on DNA synthesis in primary cultures of rat hepatocytes. Carcinogenesis 14, $281-283$.

Sutherland, L., Ebner, T. \& Burchell, B. (1993). The expression of UDP-glucuronosyltransferases of the UGT1 family in human liver and kidney and in response to drugs. Biochemical Pharmacology 45, 295-301.

Suzuki, S., Takada, T., Sugawara, Y., Muto, T. \& Kominami, R. (1991). Quercetin induces recombinational mutations in cultured cells as detected by DNA fingerprinting. Japanese Journal of Cancer Research 82, 1061-1064.

Taffet, S. M. \& Russell, S. W. (1981). Macrophage-mediated tumor cell killing: regulation of expression of cytolytic activity by prostaglandin E. Journal of Immunology 126, 424-427.

Takada, H., Hirooka, T., Hiramatsu, Y. \& Yamamoto, M. (1982). Effects of $\beta$-glucuronidase inhibitor on azoxymethane-induced colonic carcinogenesis in rats. Cancer Research 42, 331-334. 
Takahashi, S., Hakoi, K., Yada, H., Hirose, M., Ito, N. \& Fukushima, S. (1992). Enhancing effects of diallyl sulfide on hepatocarcinogenesis and inhibitory actions of the related diallyl disulfide on colon and renal carcinogenesis in rats. Carcinogenesis 13, 1513-1518.

Talalay, P., De Long, M. J. \& Prochaska, H. J. (1988). Identification of a common chemical signal regulating the induction of enzymes that protect against chemical carcinogenesis. Proceedings of the National Academy of Sciences, USA 85, 8261-8265.

Talalay, P. \& Prochaska, H. J. (1987). Mechanisms of induction of NAD(P)H :quinone reductase. Chemica Scripta 27A, 61-66.

Tanaka, T., Morishita, Y., Suzui, M., Kojima, T., Okumura, A. \& Mori, H. (1994). Chemoprevention of mouse urinary bladder carcinogenesis by the naturally occurring carotenoid astaxanthin. Carcinogenesis 15, 15-19.

Tawfiq, N., Wanigatunga, S., Heaney, R. K., Musk, S. R. R., Williamson, G. \& Fenwick, G. R. (1994). Induction of the anticarcinogenic enzyme quinone reductase by food extracts using murine hepatoma cells. European Journal of Cancer Prevention, in press.

Telang, N. T., Suto, A., Wong, G. Y., Osborne, M. P. \& Bradlow, H. L. (1992). Induction by estrogen metabolite $16 \alpha$-hydroxyestrone of genotoxic damage and aberrant proliferation in mouse mammary epithelial cells. Journal of the National Cancer Institute, 84, 634-638.

Testa, U., Pelosi, E. \& Peschle, C. (1993). The transferrin receptor. Critical Reviews in Oncogenesis 4, $241-276$.

Tong, C., Fazio, M. \& Williams, G. M. (1980). Cell cycle-specific mutagenesis at the hypoxanthine phosphoribosyltransferase locus in adult rat liver epithelial cells. Proceedings of the National Academy of Sciences, USA 77, 7377-7379.

Troll, W., Frenkel, K. \& Wiesner, R. (1984). Protease inhibitors as anticarcinogens. Journal of the National Cancer Institute 73, 1245-1250.

Troll, W., Lim, J. S. \& Belman, S. (1992). Protease inhibitors suppress carcinogenesis in vivo and in vitro. In Cancer Chemoprevention, pp. 503-512 [L. Wattenberg, M. Lipkin, C. W. Boone \& G. J. Kelloff, editors]. Boca Raton, FL: CRC Press.

Troll, W., Wiesner, R. \& Frenkel, K. (1987). Anticarcinogenic action of protease inhibitors. Advances in Cancer Research 49, 265-283.

Trosko, J. E. \& Chang, C.-C. (1984). Role of intercellular communication in tumor promotion. In Mechanisms of Tumor Promotion, vol. 4, Cellular Responses to Tumor Promoters, pp. 119-145 [T. J. Slaga, editor]. Boca Raton, FL: CRC Press.

Ursini, F. \& Bindoli, A. (1987). The role of selenium peroxidases in the protection against oxidative damage of membranes. Chemistry and Physics of Lipids 44, 255-276.

Ursini, F., Maiorino, M. \& Gregolin, C. (1985). The selenoenzyme phospholipid hydroperoxide glutathione peroxidase. Biochimica et Biophysica Acta 839, 62-70.

VanderPloeg, L. C. \& Welsch, C. W. (1991). Inhibition by caffeine of ovarian hormone-induced mammary gland tumorigenesis in female GR mice. Cancer Letters 56, 245-250.

Verhagen, H., van Poppel, G., Willems, M. I., Bogaards, J. J. P., Rompelberg, C. J. M. \& van Bladeren, P. J. (1993). Cancer prevention by natural food constituents. International Food Ingredients no. 1/2, 22-29.

Wallig, M. A., Kuchan, M. J. \& Milner, J. A. (1993). Differential effects of cyanohydroxybutene and selenium on normal and neoplastic canine mammary cells in vitro. Toxicology Letters 69, 97-105.

Wang, Z. Y., Agarwal, R., Zhou, Z. C., Bickers, D. R. \& Mukhtar, H. (1991). Inhibition of mutagenicity in Salmonella typhimurium and skin tumor initiating and tumor promoting activities in SENCAR mice by glycyrrhetinic acid: comparison of $18 \alpha$ - and $\beta$-stereoisomers. Carcinogenesis 12, 187-192.

Wattenberg, L. W. (1981). Inhibition of carcinogen-induced neoplasia by sodium cyanate, tert-butylisocyanate and benzyl isothiocyanate administered subsequent to carcinogen exposure. Cancer Research 41, 2991-2994.

Wattenberg, L. W. (1983). Inhibition of neoplasia by minor dietary constituents. Cancer Research 43, 2448S2453S.

Wattenberg, L. W. (1985). Chemoprevention of cancer. Cancer Research 45, 1-8.

Wattenberg, L. W. (1993). Inhibition of carcinogenesis by nonnutrient constituents of the diet. In Food and Cancer Prevention: Chemical and Biological Aspects, pp. 12-23 [K. W. Waldron, I. T. Johnson \& G. R. Fenwick, editors]. Cambridge: Royal Society of Chemistry.

Wattenberg, L. W., Schafer, H. W., Waters, L. \& Davis, D. W. (1989a). Inhibition of mammary tumor formation by broccoli and cabbage. Proceedings of the American Association for Cancer Research 30, 181.

Wattenberg, L. W., Sparnins, V. L. \& Barany, G. (1989 b). Inhibition of $N$-nitrosodiethylamine carcinogenesis in mice by naturally occurring organosulfur compounds and monoterpenes. Cancer Research 49, $2689-2692$.

Weed, H. G., McGandy, R. B. \& Kennedy, A. R. (1985). Protection against dimethylhydrazine-induced adenomatous tumors of the mouse colon by the dietary addition of an extract of soybeans containing the Bowman-Birk protease inhibitor. Carcinogenesis 6, 1239-1241.

Wei, H., Tye, L., Bresnick, E. \& Birt, D. F. (1990). Inhibitory effect of apigenin, a plant flavonoid, on epidermal ornithine decarboxylase and skin tumor promotion in mice. Cancer Research 50, 499-502.

Wells, W. W., Xu, D. P., Yang, Y. \& Rocque, P. A. (1990). Mammalian thioltransferase (glutaredoxin) and protein disulfide isomerase have dehydroascorbate reductase activity. Journal of Biological Chemistry 265, $15361-15364$.

Welsch, C. W., DeHoog, J. V. \& O'Connor, D. H. (1988). Influence of caffeine consumption on carcinomatous and normal mammary gland development in mice. Cancer Research 48, 2078-2082. 
Williams, D. E., Carpenter, H. M., Buhler, D. R., Kelly, J. D. \& Dutchuk, M. (1992). Alterations in lipid peroxidation, antioxidant enzymes, and carcinogen metabolism in liver microsomes of vitamin-E-deficient trout and rat. Toxicology and Applied Pharmacology 116, 78-84.

Williams-Ashman, H. G. \& Canellakis, Z. N. (1979). Polyamines in mammalian biology and medicine. Perspectives in Biology and Medicine 22, 421-453.

Winterbourn, C. C., Vile, G. F. \& Monteiro, H.P. (1991). Ferritin, lipid peroxidation and redox cycling xenobiotics. Free Radical Research Communications 12-13, 107-114.

Witschi, H. \& Kennedy, A. R. (1989). Modulation of lung tumor development in mice with the soybean-derived Bowman-Birk protease inhibitor. Carcinogenesis 10, 2275-2277.

Wortelboer, H. M., Vanderlinden, E. C. M., Dekruif, C. A., Noordhoek, J., Blaauboer, B. J., Van Bladeren, P. J. \& Falke, H. E. (1992). Effects of indole-3-carbinol on biotransformation enzymes in the rat. In vivo changes in liver and small intestinal mucosa in comparison with primary hepatocyte cultures. Food and Chemical Toxicology 30, 589-599.

Wu, L. \& Whitlock, J. P. (1993). Mechanism of dioxin action-receptor-enhancer interactions in intact cells. Nucleic Acids Research 21, 119-125.

Xanthoudakis, S., Miao, G., Wang, F., Pan, Y. C. E. \& Curran, T. (1992). Redox activation of Fos-Jun DNA binding activity is mediated by a DNA repair enzyme. EMBO Journal 11, 3323-3335.

Xu, Y., Ho, C.-T., Amin, S. G., Han, C. \& Chung, F.-L. (1992). Dietary inhibitors of chemical carcinogenesis. 17. Inhibition of tobacco-specific nitrosamine-induced lung tumorigenesis in $\mathrm{A} / \mathrm{J}$ mice by green tea and its major polyphenol as antioxidants. Cancer Research 52, 3875-3879.

Yamaguchi, T. (1980). Mutagenicity of isothiocyanates, isocyanates and thioureas on Salmonella typhimurium. Agricultural and Biological Chemistry 44, 3017-3018.

Yamamoto, S. \& Kato, R. (1992). Inhibitors of the arachidonic acid cascade and their chemoprevention of skin cancer. In Cancer Chemoprevention, pp. 141-151 [L. Wattenberg, M. Lipkin, C. W. Boone \& G. J. Kelloff, editors]. Boca Raton, FL: CRC Press.

Yamasaki, H. (1984). Modulation of cell differentiation by tumor promoters. In Mechanisms of Tumor Promotion. Cellular Responses to Tumor Promoters, pp. 1-26 [T. J. Slaga, editor]. Boca Raton, FL: CRC Press.

Yang, C. S., Brady, J. F. \& Hong, J. (1992). Dietary effects on cytochromes-P450, xenobiotic metabolism, and toxicity. FASEB Journal 6, 737-744.

Yavelow, J., Collins, M., Birk, Y., Troll, W. \& Kennedy, A. R. (1985). Nanomolar concentrations of Bowman-Birk soybean protease inhibitor suppress x-ray-induced transformation in vitro. Proceedings of the National Academy of Sciences, USA 82, 5395-5399.

Yavelow, J., Finlay, T. H., Kennedy, A. R. \& Troll, W. (1983). Bowman-Birk soybean protease inhibitor as an anticarcinogen. Cancer Research 43, Suppl., 2454s-2459s.

Yoo, J. S. H., Hong, J. Y., Ning, S. M. \& Yang, C. S. (1990). Roles of dietary corn oil in the regulation of cytochromes $\mathrm{P} 450$ and glutathione S-transferases in rat liver. Journal of Nutrition 120, 1718-1726.

Zeigler, D. M. (1991). Mechanism, multiple forms and substrate specificities of flavin containing monooxygenases. In $N$-oxidation of Drugs: Biochemistry, Pharmacology and Toxicology; pp. 59-70 [P. Hlavica and L. A. Damani, editors]. London: Chapman and Hall.

Zhang, Y., Talalay, P., Cho, C.-G. \& Posner, G. H. (1992). A major inducer of anticarcinogenic protective enzymes from broccoli: isolation and elucidation of structure. Proceedings of the National Academy of Sciences, USA 89, 2399-2403.

Ziegler, R. G. (1991). Vegetables, fruits, and carotenoids and the risk of cancer. American Journal of Clinical Nutrition 53, 251S-259S. 